\title{
Heparan Sulfate Glycosaminoglycans: (Un)Expected Allies in Cancer Clinical Management
}

\author{
Isabel Faria-Ramos ${ }^{1,2}\left(\mathbb{D}\right.$, Juliana Poças ${ }^{1,2,3} \mathbb{D}$, Catarina Marques $1,2,3$, João Santos-Antunes $1,2,4,5 \mathbb{D}$, \\ Guilherme Macedo ${ }^{4,5}$, Celso A. Reis ${ }^{1,2,3,4}$ and Ana Magalhães ${ }^{1,2, *(\mathbb{D})}$ \\ 1 Instituto de Investigação e Inovação em Saúde (i3S), University of Porto, 4200-135 Porto, Portugal; \\ iantunes@ipatimup.pt (I.F.-R.); jpocas@ipatimup.pt (J.P.); cgoncalves@ipatimup.pt (C.M.); \\ joao.claudio.antunes@gmail.com (J.S.-A.); celsor@ipatimup.pt (C.A.R.) \\ 2 Instituto de Patologia e Imunologia Molecular da Universidade do Porto (IPATIMUP), \\ 4200-135 Porto, Portugal \\ 3 Molecular Biology Department, Instituto de Ciências Biomédicas Abel Salazar (ICBAS), University of Porto, \\ 4050-313 Porto, Portugal \\ 4 Pathology Department, Faculdade de Medicina, University of Porto, 4200-319 Porto, Portugal; \\ guilhermemacedo59@gmail.com \\ 5 Gastroenterology Department, Centro Hospitalar S. João, 4200-319 Porto, Portugal \\ * Correspondence: amagalhaes@ipatimup.pt
}

Citation: Faria-Ramos, I.; Poças, J.; Marques, C.; Santos-Antunes, J.; Macedo, G.; Reis, C.A.; Magalhães, A. Heparan Sulfate Glycosaminoglycans: (Un)Expected Allies in Cancer Clinical Management. Biomolecules 2021, 11, 136. https://doi.org/ 10.3390/biom11020136

Received: 11 December 2020

Accepted: 18 January 2021

Published: 21 January 2021

Publisher's Note: MDPI stays neutral with regard to jurisdictional claims in published maps and institutional affiliations.

Copyright: (c) 2021 by the authors. Licensee MDPI, Basel, Switzerland. This article is an open access article distributed under the terms and conditions of the Creative Commons Attribution (CC BY) license (https:// creativecommons.org/licenses/by/ $4.0 /)$.

\begin{abstract}
In an era when cancer glycobiology research is exponentially growing, we are witnessing a progressive translation of the major scientific findings to the clinical practice with the overarching aim of improving cancer patients' management. Many mechanistic cell biology studies have demonstrated that heparan sulfate (HS) glycosaminoglycans are key molecules responsible for several molecular and biochemical processes, impacting extracellular matrix properties and cellular functions. HS can interact with a myriad of different ligands, and therefore, hold a pleiotropic role in regulating the activity of important cellular receptors and downstream signalling pathways. The aberrant expression of HS glycan chains in tumours determines main malignant features, such as cancer cell proliferation, angiogenesis, invasion and metastasis. In this review, we devote particular attention to HS biological activities, its expression profile and modulation in cancer. Moreover, we highlight HS clinical potential to improve both diagnosis and prognosis of cancer, either as HS-based biomarkers or as therapeutic targets.
\end{abstract}

Keywords: biomarker; cancer; cancer therapy; extracellular vesicles; glycosaminoglycans; heparan sulfate; proteoglycans

\section{Introduction}

After decades of knowledge about the cellular signalling pathways mediated by glycoconjugates and the impact of the glycan structural characteristics in defining specific cellular responses, researchers are taking advantage of the multiple features of glycosaminoglycans (GAGs) to develop new tools for improving the clinical management of cancer. GAGs are long linear chains of heterogeneous saccharides, comprising one of the major biomolecules class found in all mammalian cells [1]. GAGs have been extensively studied, and their interactions with growth factors, morphogens, chemokines, extracellular matrix (ECM) proteins and their bioactive fragments, receptors, lipoproteins and pathogens are well described [1-5]. This dynamic network orchestrates several essential functions, from critical steps in embryogenesis and early development to ECM (re)modelling and cell signalling regulation in various physiological and pathological contexts, such as metabolic and neurodegenerative diseases, infections and cancer [6,7]. This review focuses on one particular class of GAGs: Heparan sulfate (HS). HS are anionic polysaccharide chains that assemble as disaccharide building blocks of glucuronic acid (GlcA) linked to N-acetylglucosamine (GlcNAc) and undergo extensive modification through the action of at least 
four families of sulfotransferases and one epimerase. HS chains are covalently linked to a core protein to form heparan sulfate proteoglycans (HSPGs), which can be expressed at the cell membrane, released into the ECM [8] or secreted in extracellular vesicles (EVs) $[9,10]$. The HSPGs are the main mediators of cellular interaction with an enormous number of ligands. Over the last decade, new insights have emerged regarding the mechanisms and the biological significance of those interactions [7,11-13], and in this last couple of years, their biomedical potential has been at the forefront in glycobiology translational research [14-16]. HS interfere in many steps of tumour progression, such as cancer cell proliferation, immune response escaping, invasion of neighbour tissues and metastasis $[7,9,17]$. Moreover, the aberrant expression of different HSPGs and of the key enzymes involved in HS biosynthesis and post-synthesis modifications impact cancer cell behaviour [17,18]. The interplay between researchers and clinicians has been key to identify the major needs in the clinical practice, and therefore, propel a better understanding on the potential of HS with the ultimate goal of improving cancer patients' management. This ladder could not be scaled without the parallel development of powerful analytical equipment and approaches for glycan characterisation $[19,20]$. These biotechnological advances have contributed to unravel important features regarding the chemical diversity of HS structures, along with the intricate regulation of its biosynthetic pathways.

This review presents the main HS and HSPGs biological functions, from physiological to disease contexts, and summarises the most recent findings on HS as biomarkers and/or as therapeutic targets.

\section{Glycosaminoglycans as Main Extracellular Matrix and Glycocalyx Building Blocks \\ 2.1. Glycosaminoglycans and Proteoglycans Diversity}

ECM is a well-organised and dynamic macromolecular complex that provides a three-dimensional scaffold for cells and contributes to tissue homeostasis. Generally, the ECM is composed by varied fibrous proteins, polysaccharides and water. However, its major components, and subsequent structural features, are tissue-specific. Its most common constituents include collagens, glycoproteins, such as laminins and fibronectin, proteoglycans (PGs) and GAGs [21,22]. Besides acting as important ECM building blocks, PGs are also major components of the cellular glycocalyx. This cell's surface layer includes a vast group of membrane-attached PGs, secreted GAG chains, glycoproteins and glycolipids being associated with cellular functions in homeostasis, as well as to cell responses to injury and disease [1].

PGs are composed by a core protein with GAG chains covalently attached. GAGs are long and linear polysaccharides composed by repeating disaccharide units and represent an important distinctive structural feature amongst different PGs. According to the disaccharide units that build these chains, GAGs can be classified as HS, chondroitin sulfate (CS), dermatan sulfate (DS) or keratan sulfate (KS) [8]. Hyaluronan (HA) is the exception because it is the only non-sulfated GAG and lacks a covalent bond to a protein core. The different classes of GAGs are schematically represented in Figure 1A.

According to their cellular and subcellular localisation, overall homology and function, PGs can be further classified into five different groups: (i) Intracellular proteoglycans (Serglycin); (ii) Cell surface proteoglycans (syndecans (SDCs), chondroitin sulfate Proteoglycan 4/neuron glia antigen-2 (CSPG4/NG2), betaglycan/TGF $\beta$ type III receptor; phosphacan/receptor-type protein tyrosine phosphatase $\beta$; glypicans (GPCs)/GPIanchored proteoglycans); (iii) pericellular and basement membrane proteoglycans (Perlecan; Agrin; Collagens XV and XVIII); (iv) extracellular proteoglycans (Aggrecan; Versican; Neurocan and Brevican); and (v) small leucine-rich proteoglycans (SLRPs) (class I-V), which are abundant ECM glycoconjugates (decorin, biglycan, fibromodulin, luminican, kerotocan, osteoglycan) [24].

The different carriers of HS GAGs at the cellular glycocalyx are shown in Figure 1B. 


\section{A Heparin/Heparan Sulfate (HS)




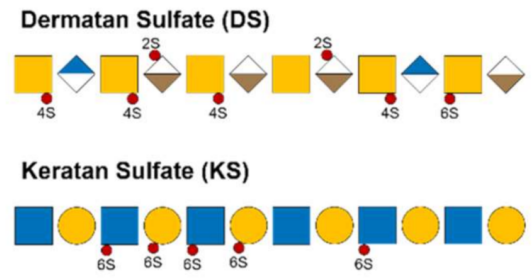

Hyaluronan (HA)
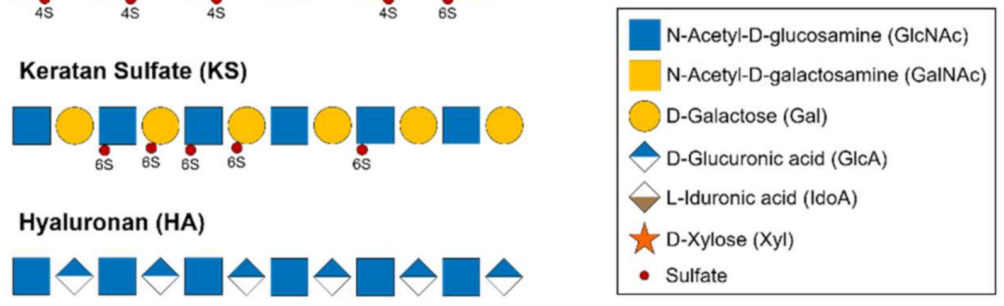

B

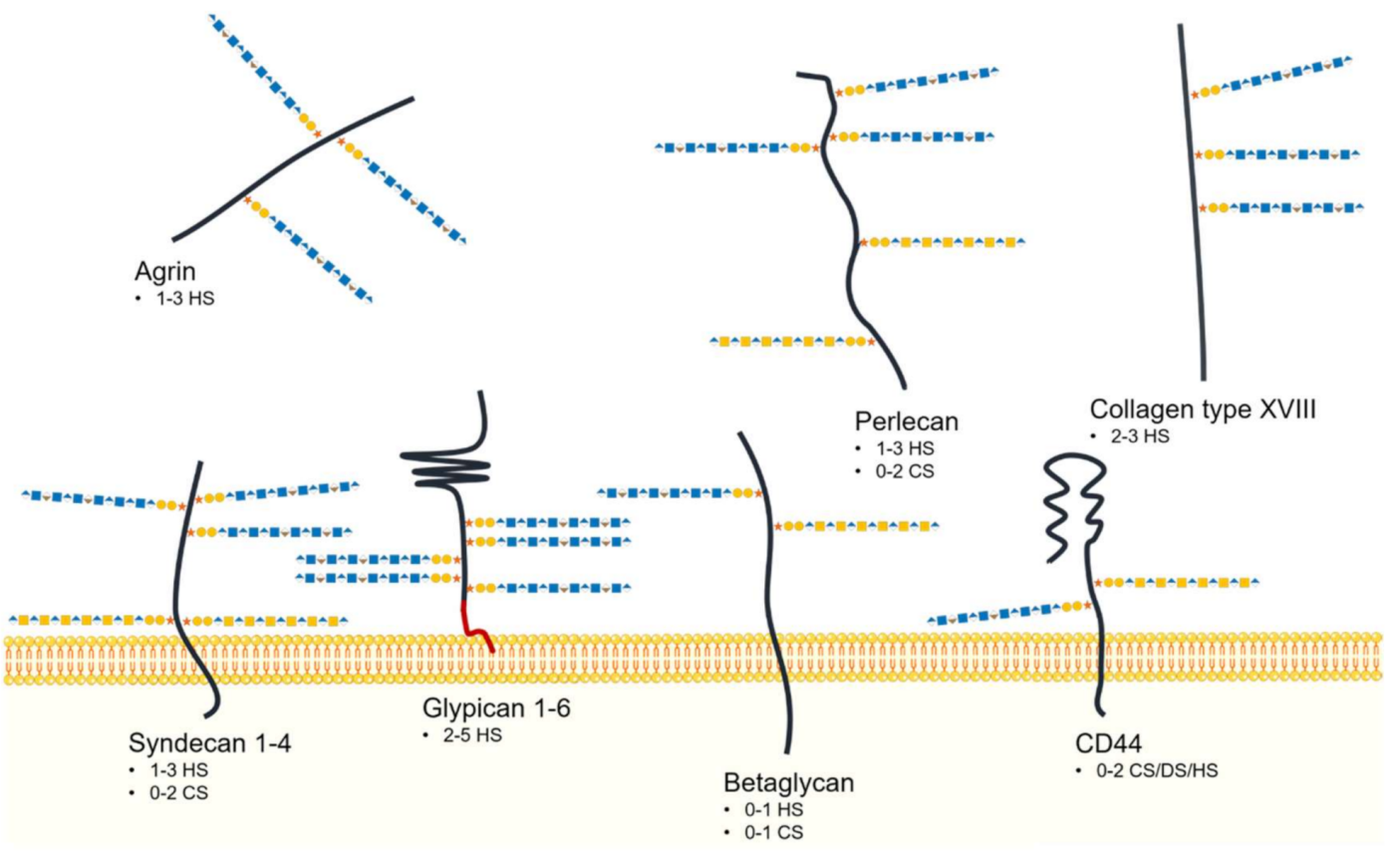

Figure 1. (A) Structural composition and classification of glycosaminoglycan chains. Non-reducing termini are to the right of the saccharide's sequences. (B) Illustrative representation of major heparan sulfate (HS)-proteoglycans composing the cells' glycocalyx and extracellular matrix (ECM). Below each family of heparan sulfate proteoglycans (HSPGs) is indicated the number and type of glycosaminoglycan (GAG) chains that commonly modify the core protein $[8,23]$.

\subsection{Heparan Sulfate Biochemical and Structural Features}

HSPGs are composed by a core protein with covalently linked HS chains, whose length ranges between 50-400 disaccharide units [25]. The glycan portion directly attached to the protein is termed tetrasaccharide linker and is composed by a residue of xylose $(\mathrm{Xyl})$ directly attached to the core protein, two galactose (Gal) residues and one GlcA residue. This region is followed by repeating disaccharide units of glucosamine and uronic acid residues. It is the sulfation pattern of these repeating units that generate large structural and functional diversity. The glucosamine residues can either be $N$-sulfated (GlcNS) or $N$-acetylated (GlcNAc), both of which can suffer 6-O-sulfation (GlcNS(6S) and GlcNAc(6S)). GlcNS and GlcNS (6S) can also be further 3-O-sulfated (GlcNS(3S) and GlcNS(3,6S)). The uronic acid residues that can either be GlcA or its epimer Iduronic Acid (IdoA), can also be 2-O- 
sulfated (IdoA(2S) and GlcA(2S)) $[6,25,26]$. These sulfation and epimerisation reactions give rise to, at least, 23 different HS disaccharide structures that constitute the sulfated (S)-domains subsequently repeated through the chains. The $S$-domains are intercalated by $\mathrm{N}$-acetylated (NA)-domains, which are enriched in less modified disaccharides, providing great variability within HS polysaccharides [25].

HS biosynthesis occurs in Golgi apparatus or at the endoplasmic reticulum (ER)-Golgi interface, and is organised in three major events: (i) GAG-protein tetrasaccharide linker assembly, through which HS are covalently attached to particular serine residues in the PG core protein; (ii) HS chains polymerisation; and (iii) structural modifications of the elongated chains [25]. The first two stages include a series of sequential steps catalysed by different glycosyltransferases. It starts with the transfer of a Xyl residue, catalysed by two $O$-xylosyltransferases (XYLT1 and XYLT2), followed by the addition of a Gal residue, by Galactosyltransferase-I/ $\beta 4$-Galactosyltransferase 7 ( $\beta 4$ Gal-T7) and subsequent transient phosphorylation of the $\mathrm{Xyl}$ residue mediated by the kinase FAM20B. This last step is essential for the following reactions of assembly, as it enhances the activity of subsequent glycosyltransferases, namely, the Galactosyltransferase-II/ $\beta 3$-Galactosyltransferase 6 ( $\beta 3 \mathrm{Gal}-\mathrm{T} 6)$, which will then add the second residue of $\mathrm{Gal}$ to the nascent polysaccharide chain $[27,28]$. The biosynthesis of the tetrasaccharide linker (GlcA $\beta 1-3 \mathrm{Gal}-\beta 1-3 \mathrm{Gal}-\beta 1$ 4 Xyl- $\beta 1-O-S e r$ ) is completed once the Glucuronyltransferase I (GlcAT-I) adds a GlcA residue to the extremity of the chain, in a reaction step that occurs simultaneously with the dephosphorylation of the Xyl residue by the 2-Phosphoxylose phosphatase (XYLP) [29].

Knock-out $(\mathrm{KO})$ cellular glycoengineering showed that abrogation of XYLT2 in CHO cells that do not express XYLT1, abolished HS biosynthesis. Additionally, elimination of B4galt7 and B3gat3 (GlcAT-I) gene expression also fully impaired GAGs biosynthesis, while the $\mathrm{KO}$ of the genes coding for the enzymes $\beta 3 \mathrm{Gal}-\mathrm{T} 6$ and FAM20B only reduced its synthesis [30]. Koike et al. conducted silencing experiments in HeLa cells and observed great reduction of the levels of HS chains in lower XYLP expressing cells, suggesting that the dephosphorylation of xylose residues is necessary for correct tetrasaccharide linker assembly [29]. However, more recently, it was determined that the KO of Pxylp1, performed on CHO cells, did not alter the levels of GAGs [30]. These results indicate that the role of XYLP in the maturation of the tetrasaccharide linker might be dependent of the cellular context.

The above-mentioned enzymatic steps are common to the biosynthesis of heparin/HS and CS/DS GAG chains, while the following events dictate the biosynthesis of a particular type of GAG chains. Focusing on HS, the addition of a GlcNAc residue to the linkage tetrasaccharide initiates the polymerisation of these chains (in detriment of the polymerisation of CS chains). This reaction involves the catalytic activity of two members of the Exostosin (EXT) family, EXT-like proteins 2 and 3 (EXTL2 and EXTL3), and is followed by further elongation promoted by a hetero-oligomeric complex formed by EXT1 and EXT2 that mediates the intercalated transfer of GlcNAc and GlcA residues [31-34].

EXTL3 acts as a highly efficient $\alpha 1,4$-GlcNAc transferase towards mature tetrasaccharide linkers by adding the first GlcNAc to the HS chains [32]. Different in vitro and in vivo models have revealed that KO of EXTL3 results in the abolition of HS biosynthesis, uncovering the crucial role of this enzyme in initiating the elongation of HS chains $[30,35,36]$. The regulatory activity of EXTL2 in this step stills raises significant doubt. EXTL2 is characterised as an $\alpha 1,4-N$-acetylhexosaminyltransferase, displaying dual in vitro catalytic activity by adding both GlcNAc and GalNAc residues to linker mimetics. It has been demonstrated that this glycosyltransferase cannot add GlcNAc residues to mature tetrasaccharide linker substrates [33], however it exhibits significant $N$-acetylglucosamine-transferase activity towards phosphorylated forms of the tetrasaccharide linker. By adding a GlcNAc residue to immature linker structures (GlcA $\beta 1-3 \mathrm{Gal} \beta 1-3 \mathrm{Gal} \beta 1-4 \mathrm{Xyl}(2-\mathrm{O}-\mathrm{phosphate})-\beta 1-$ $O-S e r)$, EXTL2 promotes the synthesis of phosphorylated pentasaccharides (GlcNAc $\alpha 1$ 4GlcUA $\beta 1-3 \mathrm{Gal} \beta 1-3 \mathrm{Gal} \beta 1-4 \mathrm{Xyl}(2-\mathrm{O}-$ phosphate)- $\beta 1-O-S e r)$ that neither EXT1 nor EXT2 can further polymerise, ultimately resulting in premature HS chains termination [37]. 
This is in accordance with the increased HS content reported in EXTL2 KO cell models [30] and EXTL2 deficient mice $[37,38]$.

Once polymerised, HS chains are matured by HS modifying enzymes, including $\mathrm{N}$ Deacetylase/N-Sulfotransferases (NDST1-4), C5-epimerase and different Sulfotransferases (2OST, 6OSTs, 3OSTs) and sulfatases (Sulf-1 and Sulf-2) [6,39]. HS chain features are not directly encoded by the genome, showing a high level of heterogeneity and large structural diversity in terms of monomer sequence, chain length and sulfation profile, all due to post-translational modifications regulated in the Golgi [25]. Therefore, the resulting HS chains are involved in multiple biological processes, varying over different organs [40,41], stages of development [42-44] and pathologies $[45,46]$. HS chains sulfation and length are crucial to the roles displayed by HSPGs, as these determine the binding affinity to the respective targets. The HS sulfation degree, in particular, confers high negative charge to GAGs, prompting HSPGs to interact, in a non-covalent ionic manner, with several proteins [12].

\section{Heparan Sulfate Biological Activities}

\subsection{In Physiology}

HS are loaded with biological roles, as illustrated in Figure 2A. Acting as mediators in a multitude of regulatory mechanisms, ranging from embryonic development to ECM assembly and regulation of cell signalling $[6,47,48]$. HS interact with a plethora of molecular partners, including soluble proteins (growth factors, morphogens and chemokines), ECM proteins, bioactive fragments and membrane receptors, such as integrins and receptor tyrosine kinase (RTKs). HS chains also promote pathogen attachment and invasion of specific tissues by binding to numerous microorganisms, including viruses, bacteria, parasites and fungi $[2,5,49-51]$. Moreover, HSPGs are expressed in all main organ systems having essential roles in several biological activities like metabolism regulation, transcellular transport, cellular communication, ECM support and modulation. The classical role attributed to cell surface HSPGs was to assist as signalling co-receptor for growth factors activity, allowing a correct presentation to their cognate receptors and helping to stabilise gradients, to control the range of signalling and to protect the proteins against degradation [1]. However, it has been increasingly accepted that besides these co-receptor functions, HSPGs stand alone as key regulators of cell behaviour [52].

During embryonic development, HSPGs modulate the morphogen gradients distribution and other extracellular ligands signalling involved in the formation of the different tissue architectures [53]. In this light, the particular interaction of HS with the Hedgehog signalling pathway is very important to a proper embryonic development [54]. Similarly, HSPGs, being the most abundant PGs in basal lamina and cell surface of skeletal muscle, have been shown to regulate fibroblast growth factor (FGF), Wnt and bone morphogenetic protein pathways, fundamental for the development of skeletal structures [55].

More recently, it was revealed that SDCs can regulate calcium channels of the TRPC (transient receptor potential canonical) family, with functional consequences on the actin cytoskeleton, cell adhesion, junctions and migration. Moreover, this interaction was suggested to be evolutionary conserved and relevant for the progression of some diseases [48,56].

HSPGs are also important modulators of metabolism, as illustrated by their role in the liver mediated clearance of triglyceride-rich lipoproteins [57]. Additionally, several SDCs and GPCs have been implicated in the uptake of different forms of lipoproteins [58-60].

Given the many essential cellular and developmental processes in which HS and HSPGs are involved, it is expected that modifications in HSPG expression and structure contribute to a dysregulation in function and lead to pathological scenarios, such as cancer $[12,17]$. In Section 4 , we address several cancer cellular features that are regulated by changes in expression, glycosylation and sulfation profiles of HSPGs, which in turn translate into cancer progression. 


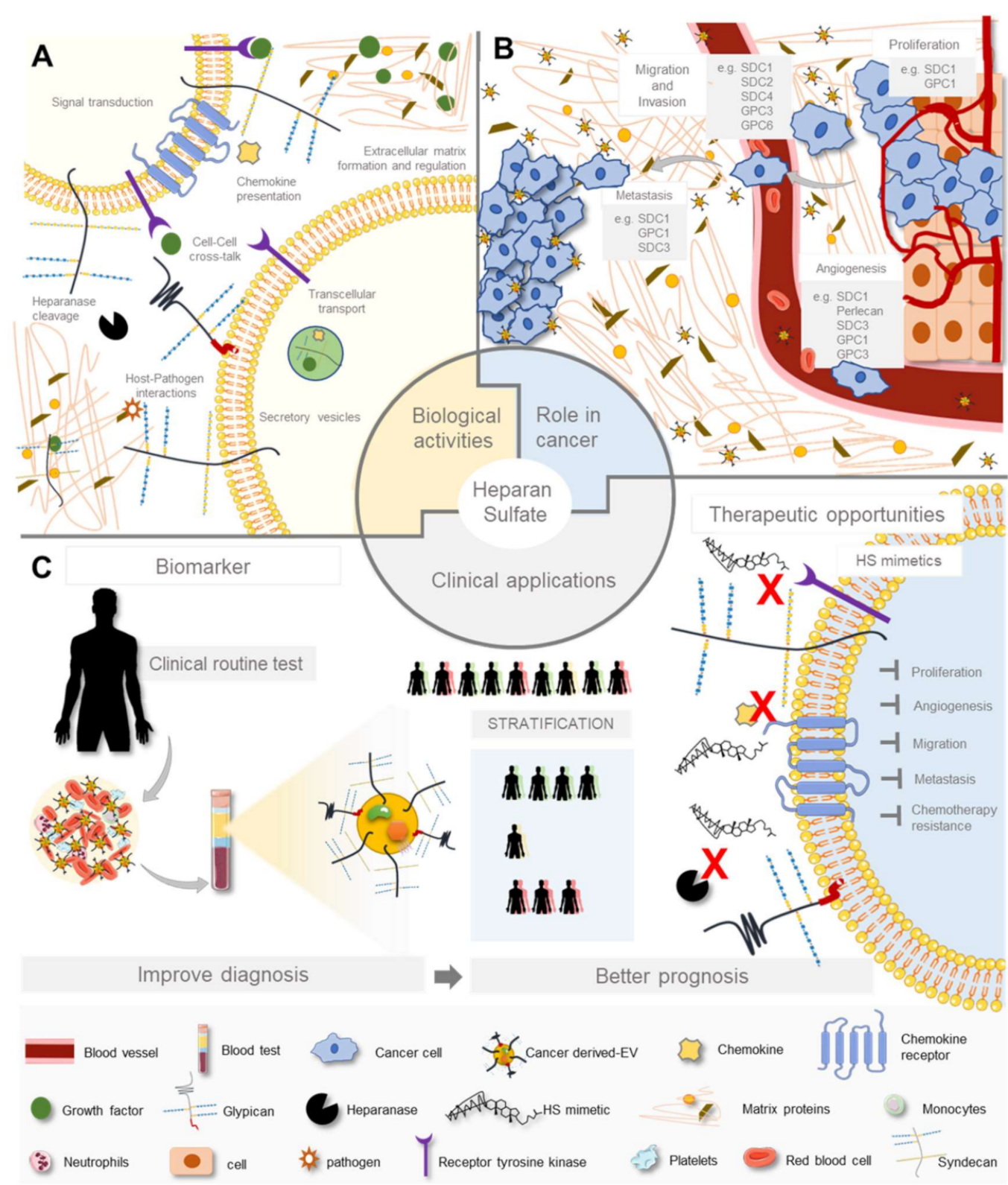

Figure 2. Overview of heparan sulfate proteoglycans functions. (A) HSPGs roles in cellular activities, (B) HSPGs aberrant expression and functional implications in cancer and (C) HSPGs biomedical potential as a biomarker and as a therapeutic target regarding cancer improved diagnosis and prognosis.

\subsection{In Inflammation}

Inflammation represents a first line protection mechanism for any harmful stimuli. Some of the major events during inflammation are regulated by HS, ranging from immune cells recruitment, adhesion and rolling, to transmigration phenomena [61]. Changes in the expression of HPSGs and HS differ depending on the type of inflammatory stimuli [62]. One of the main roles of HS and HSPGs is to drive the extravasation and migration of inflammatory cells from the vasculature into tissues, where they establish and provide cytokine gradients [63]. Moreover, HSPGs are involved in developing the basement membrane barrier, providing a structure for epithelial support and regulating the transport of solutes $[61,64,65]$. Perlecan, agrin and collagen XVIII in ECM and basement membrane interact with matrix proteins, such as fibronectin and laminin, and provide support, resistance to mechanical stress and filtration barrier properties [66]. Ultimately, HS chains 
of HSPGs bind to growth factors that are involved in tissue growth and repair, making them available at sites of tissue remodelling [67].

\subsection{In Host-Pathogen Interaction}

HS chains provide the gateway for many microorganisms, ranging from normal microbiota to various pathogenic bacteria, viruses and parasites, by mediating adherence to the host cells. This is a crucial step for infection to occur and pathogens exploit the host HSPGs to accomplish it and invade host cells. The previously described structural diversity of the HSPGs offers multiple binding sites and the degree of variability within tissues results in the tissue-specific tropism of some infectious agents $[5,51,68,69]$.

Among the pathogens that bind to host HS chains are parasites like Plasmodium falciparum [70]; bacteria, such as Escherichia coli [71], Pseudomonas aeruginosa [72], Borrelia burgdorferi [73] or Mycobacterium tuberculosis [74]; and many viruses, amongst which are found Human Papilloma virus, Herpes viruses and Human Immunodeficiency Virus$1[75,76]$. In addition, recently it was reported that severe acute respiratory syndrome coronavirus 2 (SARS-CoV-2) entry in human cells is mediated through the binding to HS chains in a length and sequence-dependent manner [49,77-80]. The interference with the HS-mediated adhesion steps can represent an effective therapeutic approach for these pathogens and can be achieved by the competition with HS mimetics and other highly sulfated polysaccharides [81]. In addition, some pathogens can release GAGs from host cell surfaces and ECM, and use these solubilised GAGs to coat their surface, deceiving and eventually escaping immune detection [82].

\section{Heparan Sulfate and Heparan Sulfate Proteoglycans Aberrant Expression in Cancer 4.1. Heparan Sulfate Changes in Cancer}

Several hallmarks of cancer, such as continuous growth signalling, abrogation of apoptosis, deregulated metabolism, immune evasion and angiogenesis are boosted through pathological alterations of normal physiological processes [83-85]. There is cumulative evidence that changes in cellular glycosylation are concomitant with the acquisition of cellular features involved in tumour growth and progression and ECM remodelling. The glycosylation alterations described in cancer include the expression of truncated O-glycan structures, increased expression of branched $\mathrm{N}$-glycans, de novo expression of sialylated glycans, altered fucosylation and aberrant PGs expression and modification [86,87].

HS chains are key modulators of cancer cell proliferation events, intervening in altered signalling by interacting with growth factor receptors, promoting their dimerisation and consequent activation, leading to overstimulation of downstream signalling cascades [88]. As an example, in multiple myeloma cells, SDC1 was shown to interact with HGF via HS chains, promoting enhanced activation of Met and consequent activation of the $\mathrm{PI} 3 \mathrm{~K} /$ protein kinase B and RAS-Raf MAPK pathways, which are related to cell proliferation and survival [89]. In addition, the activation of the $\mathrm{Wnt} / \beta$-catenin cascade in multiple myeloma is also promoted by HS chains of SDC1, leading to cancer cells proliferation [90].

Besides the altered expression of HSPGs, the abnormal activity of HS biosynthetic and post-synthetic enzymatic machinery, which determines HS chains' length, epimerisation, acetylation and sulfation patterns, is also known as a major event behind HS deregulation in cancer [91]. Comparative studies demonstrated that the expression of genes coding for HS biosynthetic machinery is deregulated in several types of cancer, weighing on its role in carcinogenic events [92]. In colorectal cancer, it was shown the aberrant expression of enzymes that catalyse uronic acid structural changes (epimerisation and 2-O sulfation), and enzymes that impact glucosamine residues sulfation pattern (NDST1 and 2,6OST isoforms $3 \mathrm{~B}, 5$ and 6 ), depending on the anatomical location and the metastatic nature of the tumours [93,94]. HS modifying enzymes were also shown to present deregulated expression on breast cancer tissue samples [46]. As for glycoenzymes that intervene in HS polymerisation, the analysis performed using estrogen receptor positive and triple negative breast cancer cell lines revealed altered expression of EXT1, EXT2, EXTL2 and EXTL3 [95]. 
HS 6-O-sulfation levels, determined by the expression of 6OSTs, have been reported as critical for the activation of epidermal growth factor receptor (EGFR) by heparin bidingEGF (HBEGF), and the consequent increase in the expression of angiogenic cytokines on ovarian tumour cells [96]. In lung cancer, 3OST2 hypermethylation and consequent deregulation, was associated with lung tumourigenesis and poor overall patient survival, possibly resulting from the altered HSPGs ability to interact with proteins participating in cell growth and adhesion [97]. Likewise, the hypermethylation in HS 6-O-endosulfatase Sulf-1 promoter region downregulates its expression in gastric cancer cell lines and tissue samples [98], and the decreased levels of HS 6-O-endosulfatase associate with gastric cancer progression [99]. Conversely, the sulfatase Sulf- 2 is described to be overexpressed in hepatocellular carcinomas and associated with worse prognosis [100].

Heparanase (HPSE), a $\beta$-D-endoglucuronidase, is the only mammalian enzyme known to cleave HS and is one of the most studied glycosylation-related enzymes in cancer [101,102]. This enzyme is known to be a tumour inducer acting in several signalling pathways modulating angiogenesis, cell proliferation, migration and metastasis [103-105]. HER2- and EGFR-positive breast cancer cells resistant to lapatinib, a tyrosine kinase inhibitor that blocks the activation of the EGFR and HER2 pathways, revealed increased activity of HPSE. This feature was associated with enhanced activation of EGFR, FAK and ERK1/2 signalling pathways and subsequent cell growth. HPSE inhibition, was shown to sensitise these cells to lapatinib and inhibit formation of brain metastases [106]. More recently, vascular endothelial growth factor receptor 3 (VEGFR3)expressing macrophages and cathepsin release, both playing a significant role in metastasis formation in chemotherapy-treated tumours, were found to promote lymph angiogenesis as a result of VEGF-C upregulation by HPSE [107]. Autophagy is another cellular attribute modulated by HPSE. This catabolic pathway maintains homeostasis in normal cells, while it is completely hijacked in several tumours, promoting cancer cell survival. Autophagy induced by lysosomal HPSE has been shown to enhance tumour development and chemoresistance [108-110]. Although HPSE activity has been mainly described extracellularly or within the cytoplasm, nuclear HPSE has also been reported [111-113]. In melanoma, nuclear HPSE was shown to suppress tumour progression by competing for DNA binding and inhibiting the transcription of genes, such as those coding for ECMdegrading enzymes that promote metastasis formation [112]. In multiple myeloma disease context, HSPE was recently associated with chromatin opening and transcriptional activity concomitant with downregulation of PTEN tumour suppressor activity [111]. Also supporting the role of HPSE in tumour progression and metastasis formation, HPSE has been shown to promote EV secretion by tumour cells, affecting its protein cargo [114,115], and modulating HS structure on recipient cells to facilitate EVs internalisation $[9,115,116]$.

\subsection{Role of Heparan Sulfate and Heparan Sulfate Proteoglycans in Cancer Cellular Features and Extracellular Matrix Remodelling}

Cancer cells undergo relevant morphological changes, such as the epithelial to mesenchymal transition (EMT), to increase motility capacity. HS chains play a key role in this transition, due to their binding affinity to key growth factors secreted into the tumour microenvironment $[117,118]$. Particularly, upregulation of SDC4, in lung adenocarcinoma, was shown to stimulate cell's migration and invasion via TGF- $\beta 1$, accompanied by induction of EMT [119]. Cell proliferation is also a crucial characteristic of malignant transformation. The HSPGs GPC1 and SDC1, overexpressed in a high percentage of breast cancer pathologies, enhance the mitogen effects associated with heparin-binding growth factors like Basic Fibroblast Growth Factor (FGF2), HBEGF and Hepatocyte growth factor (HGF), promoting cell proliferation [120]. Some studies have shown that HS and HSPGs can translocate to the nucleus and contribute to gene expression regulation [121,122]. Although the role of nuclear HSPGs is still not fully uncovered, another important role of nuclear HSPGs is the translocation of specific cargo to the nucleus. Nuclear translocation of SDC1 was shown to regulate tumour signalling by shuttling growth factors to the nucleus and by altering histone acetylation [123]. 
Tumour progression is accompanied by the development of new blood vessels [124]. HS chains, by binding to angiogenic growth factors, namely, FGFs, platelet-derived growth factors and VEGFs, dictate HSPGs relevant roles in angiogenesis [91,125,126]. It has been shown that HS presence on endothelial-cells' surface can serve as a binding site for the potent antiangiogenic factor endostatin. Several studies have indicated that the HS binding site for endostatin is distinct from that of pro-angiogenic factors, such as FGF. This raises the possibility that endothelial cells modulate their HS cell-surface profile to become either more or less sensitive to angiogenic signals from a growing tumour [127]. As referred earlier, SDC1 overexpression in multiple myeloma was also shown to promote angiogenesis by its ability to physically interact with VEGFR2 and prevent the receptor recycling [128]. Perlecan is also an important player in angiogenesis, since its expression is abnormally high in the basement membranes of highly metastatic human melanoma tumour cells [129], promoting the binding of pro-angiogenic FGF2 to its receptors, and consequently increasing angiogenesis [130]. In addition, SDC3 expression is positively associated with angiogenesis in neuronal and brain tissues [131,132].

Beyond the structural modifications of HS and pattern of sulfation, mentioned in Section 4.1, alterations in the HS levels can compromise the stiffness of the ECM, thus modulating cell adhesion and migration. A steady ECM does not offer the best conditions for cell migration, preventing or delaying cell motility. In this light, the ability of cancer cells to invade the surrounding tissues is modulated by changes in the expression of HS and HSPGs, which mediate several events of cell-matrix interaction, and the secretion of HPSE and metalloproteinases that allow cells to penetrate the basement membrane and ECM to invade surrounding tissues $[118,133,134]$. In hepatocellular carcinoma, SDC1 and SDC4 are key for migration, invasion and increased motility mediated by chemokine-SDC interactions [135]. SDC1 abnormal expression, for example, is determinant in tumour cell growth, invasion and migration in different types of cancer, such as colorectal, gallbladder and oesophageal carcinomas [136-139]. SDC2 overexpression in breast [133,140], colon [141] and pancreatic [142] tumour cells, is associated with altered cell morphology, focal adhesion formation, spreading, enhanced migration and invasion capabilities, and overall to a more aggressive tumour cell behaviour and disease progression [143]. GPCs are also frequently reported to play a part in cancer progression. GPC1, for instance, when upregulated, increases tumour angiogenesis and metastasis in pancreatic cancer [144,145]. In addition, GPC1 modulates heparin-binding growth factors and plays a role in tumour progression in breast cancer $[46,120]$. In esophageal squamous cell carcinoma and glioblastomas, GPC1 is also upregulated and associated with tumour angiogenesis and patients' poor prognosis [146-148]. GPC3 is overexpressed in hepatocellular carcinomas tissues [149], and associates with higher invasion and migration [150]. Similar to GPC1, an increased expression of GPC6 has been reported in breast cancer. GPC6 overexpression stimulates cancer invasion through NFAT (nuclear factor of activated T-cells) signalling pathwaypreviously reported as an inducer of pro-invasion and migration gene expression [151].

Cancer cells ability to penetrate blood vessels is preponderant for metastatic spread and is followed by circulation through the intravascular stream and establishment in other sites [152]. During the process of metastasis formation, the reorganisation of HSPGs in the ECM, creates an opportunity for new partners to bind to tumour stroma. This process also involves interactions between cancer cells and platelets, endothelial cells and host organ cells, being HS implicated in the formation of tumour metastasis in sites, such as the liver, lungs or spleen [91,153]. Moreover, SDC1 expression was shown to decrease in hepatocellular [154] and colorectal [155] carcinomas, resulting in more invasive phenotypes, with higher metastatic potential.

HS can also contribute for the immune system deceiving to either disregard or promote the tumour growth [156]. In breast cancer for example, SDC1 has been suggested to act both as a regulator of cancer stem cell (CSC) phenotype and as a modulator of lymphocytes, in particular of T helper cells, depending on the subtype of the disease [157]. 
A schematic representation of HSPG functional implications in cancer progression and their clinical potential is illustrated in Figure 2B,C.

\subsection{Heparan Sulfate Roles in Cancer Intercellular Communication}

Cancer cells communication within the tumour microenvironment is key to defeat stromal challenges, settle and colonise distant sites, leading to metastasis. Despite being the main cause of cancer therapy failure and responsible for the greatest number of cancerrelated deaths, metastasis remains poorly understood [158]. It is widely recognised that the process of cancer cell systemic circulation and the development of metastasis requires the participation of several glycoconjugates [86,159].

For years, EVs were thought to be a reservoir of cells undesired material. However, in the last two decades, they have emerged as main players in cellular communication $[160,161]$. EVs are delimited by a lipid-bilayer and can be classified into different classes, including exosomes, microvesicles and apoptotic bodies. Briefly, EVs are secreted to the environment by all cells and carry bioactive cargo that deliver signals and induce several pathophysiological events in the ECM and recipient cells [162,163]. Regarding cancer, EVs have been demonstrated as important signalling nanoparticles in pre-metastatic niche definition and metastasis [164,165].

The EV cargo includes nucleic acids, proteins, lipids and metabolites [166]. Although several seminal studies have addressed in detail the lipid, protein and nucleic acid contents of EVs, the glycans, and particularly GAGs, remain poorly characterised. However, their biological importance is emerging [160,167,168].

Importantly, HSPGs have been described as key regulators of EVs biogenesis (Figure 3) [162,169]. The biogenesis of EVs depends on the small intracellular adaptor syntenin [170], its interaction with SDC [169] and the endosomal-sorting complex required for transport accessory component ALIX [171-173]. Moreover, HPSE can stimulate intraluminal budding of SDC-syntenin-ALIX complex promoting EVs secretion [174-176]. Recently, it was described that tetraspanin-6 (TSPN6) may act as a negative regulator of exosomes release through the promotion of SDC4 and syntenin degradation. This interaction highlights the importance of the interplay between these membrane glycoproteins to produce exosomes [10].

Furthermore, it has been demonstrated that HSPGs, namely, SDCs and GPCs, are critical internalising receptors of cancer cell-derived EVs and determine their functional activity (Figure 3) [116,160]. Very recently, it was shown that under hypoxia stress, the uptake of EVs is upregulated, through a mechanism dependent on HSPG receptors and lipid raft mediated endocytosis [177].

EVs exhibit several distinctive features, from a longer half-life provided by increased resistance to degradation, therefore offering their cargo a higher stability, to the ability of travelling long distances. Furthermore, EVs can carry multiple cargo possibilities and also exhibit a unique interactive surface area [178], which may establish contact with both cells and components in the ECM microenvironment [179]. HSPGs are herein important mediators with several functions from EV secretion and trafficking to their uptake $[60,116,180]$.

Taking together glycan and EVs functional relevance in cancer development, it is not surprising that glycans in EVs have been implicated in cancer cells proliferation, angiogenesis, therapeutic resistance [181], control of metabolic activity, and immune system evasion mechanisms [160]. 


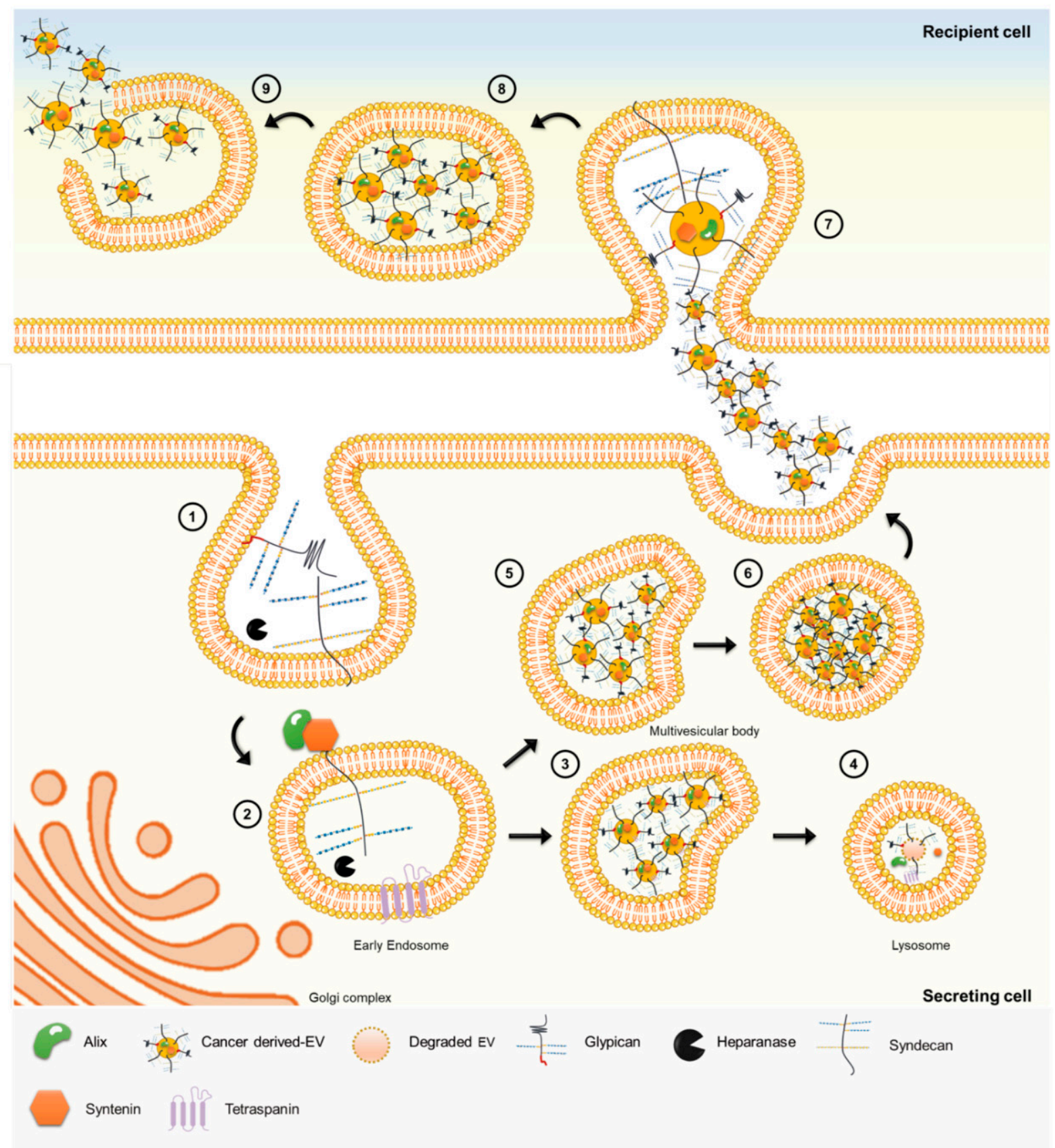

Figure 3. Heparan sulfate proteoglycans regulate EV biogenesis and uptake. (1) Cell surface HSPGs can bind multiple ligands through their GAG chains [9]. GAGs can be modified by heparanase activity [174]. (2) Syndecan is internalised through endocytosis process, leaving the cytosolic domain clear for syntenin and Alix proteins binding [160,171]. The early endosomes generate the MVBs by inward budding of theirmembrane. (3) EVs, particularly those enriched in tetraspanin-6 (TSPN6), can end on lysosome [10] (4) with consequently degradation of their content. (5) Alternatively, EVs generated inside of the MVBs can be expelled from the secreting cell, through exocytosis. (6) After fusion with cellular membrane EVs are released to the extracellular milieu. (7) HSPGs, and specifically GAGs, are important receptors of the cell membrane-EV surface cluster and are directly involved in EV uptake by recipient cell [116]. (8) After, the complex is internalised by the recipient cell. (9) EV-endosome membrane fusion occurs, and EV content is released to cytoplasmic compartment of the recipient cell, and new biological information is transferred [162]. 


\subsection{Impact of Heparan Sulfate in Cancer Cell Resistance to Therapy}

Cancer treatment relies upon four main approaches: surgery, radiation therapy, chemotherapy and immunotherapy. Some individuals will only require one treatment, but most often, a combination of treatments is used to tackle the resistant nature of cancer. Surgery can be used for solid tumours that are located in reachable areas of the body. Nevertheless, many cancers are metastatic or have a high risk for metastasis formation, implying the use of more aggressive treatments, such as radiotherapy and chemotherapy [182].

A great body of evidence indicates that tumour sensitivity to drug treatment is affected by glycosylation, particularly by altered expression of cell-surface HSPGs and/or HPSE $[17,87]$. GPCs and SDCs are usually implicated in chemo-resistance. GPC3 overexpression has been described to lead to a decrease in the accumulation of drugs associated with atypical multidrug resistance in gastric cancer [183], and high levels of GPC1 expression in patients with oesophageal squamous cell carcinoma are related to chemo-resistance [146]. As previously mentioned, SDC1 overexpression correlates with a malignant phenotype and, in addition, it is also implicated in resistance to cytotoxic or targeted therapeutics in breast cancer and multiple myeloma [157,184-188]. SDC1 levels in pre-chemotherapy breast cancer biopsies correlate with decreased response to treatment with cyclophosphamide and epirubicin [189]. Additionally, the sensitivity of breast cancer cells to trastuzumab is associated with the availability of HS chains on the cell surface and their ability to elicit the antibody response by forming a ternary complex with trastuzumab and HER2 [190].

Cancer cells resistance occurs not only to chemo, but also to radiotherapy. For example, in pancreatic cancer, HPSE was found to be overexpressed throughout the process of ionising radiotherapy, resulting from the downregulation of the transcription factor EGR1, which leads to the upregulation of HPSE and promotes tumour cells invasion [191]. In cervical cancer, HPSE expression was shown to enhance angiogenesis and radiation resistance through the hypoxia-inducible factor 1 (HIF1) pathway [192]. In addition, the interplay between SDC1 and HPSE, through indirect stimulation of HSPG shedding by metalloproteinases, and consequent activation of HS-binding growth factor signalling, was suggested to associate with colorectal cancer cells resistance to chemotherapy [193]. Clinical drugs used for myeloma showed to induce SDC1 shedding, due to the upregulation of HPSE expression. Then, HPSE can be internalised by both tumour cells and macrophages, promoting the transcription of pro-tumourigenic genes. This paradox effect leads to tumour recurrence by recreating a new cancer microenvironment, which induces chemo-resistance [188,194]. On the other hand, as referred to in Section 4.1, HPSE can modulate EVs cargo and enhance its secretion. In breast cancer models, it was shown that in a chemotherapy context, the production of EVs is increased, with upregulation of the levels of annexin A6 and promotion of metastasis [195].

It is important to note that several enzymes are involved in GAGs remodelling, and alterations on their activity can lead to the activation of compensatory routes. The variable levels of HS, CS/DS and HA over each other can lead to unusual GAG profiles, which need to be considered when a GAG-target therapeutic approach is being evaluated, since these biomolecules compete for some common substrates. [196].

\section{Heparan Sulfate Clinical Applications-Recent Advances}

\subsection{Adding Heparan Sulfate to the Equation}

The knowledge of the molecular mechanism underlying cancer biology has mightily increased over the last 30 years. The current challenge is to translate this information into benefits for patient care and to convert the new molecular information into therapy and better non-invasive biomarkers.

One of the most obvious cancer-related challenges is the heterogeneity in cancer biology [197]. Again, the challenge is the molecular and cellular heterogeneity of a single tumour, and among tumours from different patients, resulting in the very difficult task 
to design and select effective therapies without promoting treatment resistance [198,199]. Hereupon, targeting HSPGs and enzymes involved in HS chain editing, as a new anticancer strategy, seems to be a sweet spot of opportunity to deal with these challenges (Figure 2C).

Several different therapies using GAG-based strategies have been reported, and a few HS-specific treatments are on clinical trials [200]. Many new approaches to cancer treatment are emerging, and targeting HS constitutes a novel promising strategy for cancer clinical management [102,201]. These strategies include inhibition of tumour invasion and metastasis using non-anti-coagulant low-molecular-weight heparin (LMWH) analogues and inhibition of tumour progression using HS-mimetics. In animal cancer models, LMWHs were shown to inhibit metastases, diminish primary tumours and increase survival. However, pre-clinical studies have conflicting findings showing an absence of efficacy in reducing disease progression [202].

Likewise, the HPSE contribution to immune regulation is raising clinical interest. Among HS modifying enzymes, HPSE is definitely one of the most investigated as a cancer drug target $[105,175,185,188,203,204]$. Early observations of the powerful HPSE inhibitory activity of heparin lead the way for the screening of heparin/HS mimetics as HPSE inhibitors [102,205-208].

Noteworthy, substantial research has been devoted to elucidating the roles that EVs play in the regulation of both normal and pathological processes, and recently multiple studies have demonstrated their potential as a source of cancer biomarkers referred to as "liquid biopsies" [160,209]. Biomarkers for early detection of cancer are essential to improve patients' clinical management. Based on several reports showing proof-of-concept results for EV-associated pancreatic cancer biomarkers, GPC1 was the first candidate to enter clinical trials, aiming to evaluate its performance as a biomarker [210]. Consequently, various EV-associated biomarkers have been reported for early detection, diagnosis, treatment monitoring, metastasis burden, prediction and prognosis in cancer patients [211].

Along the next sections, we present some representative examples of HS-related mimetics, therapeutic targets, and biomarkers recently studied, under clinical trials evaluation or already introduced in medical practice.

\subsection{Heparan Sulfate-Based Therapeutic Opportunities}

Based on promising preclinical data, some HS-based therapies are currently under clinical investigation although none was yet approved [212-214]. Difficulties in interpreting data with HS mimetics are mainly due to their pleiotropic effects $[160,206,207]$.

Currently, leukocyte-based anticancer therapies like Chimeric Antigen Receptor-T (CAR-T) cell therapy, dendritic cell vaccines and viral-therapeutic delivery exploiting HPSE are being developed [102,215]. HPSE is able to change the function of HSPGs in the tumour microenvironment and is a regulator of several cancer hallmarks [216], namely, angiogenesis and the development of metastasis [105,217]. So, targeting HPSE and modulating its activity is a very valuable strategy to overcome several cancer features and improve disease outcome [102,218].

Another possible opportunity for intervention could be the use of the endostatin domain of collagen XVIII. Endostatin exerts an efficient inhibitory effect on tumour angiogenesis and growth $[219,220]$. Gastric cancer patients with subsequent liver metastasis are extensively studied, and several phase II clinical trials are using recombinant endostatin (either alone or combined with other drugs) as an anti-tumour agent [221-223]. In addition, the effect of endostatin in advanced well-differentiated pancreatic neuroendocrine tumours is being tested [224].

Synthetic peptides that interfere with the interaction between HS and its binding partners, also represent an appealing alternative [225]. This approach allows a specific blocking of interaction with the growth factors, acting on particular pathways. Furthermore, a large number of small molecules can also regulate glycosylation by modulating glycosyltransferases and glycosidases activity [218,226] and are emerging as new therapeutic strategies [226-228]. 
Recently, another class of enzymes have been capturing attention: the 3-O-sulfotransferases (3OSTs). These enzymes produce a rare HS modification, glucosaminyl-3-O sulfation, which affects the selective binding of several ligands. Interestingly, these enzymes can either act as pro or anti-tumourigenic according to the cellular specific context $[229,230]$. An important challenge in this field is to determine how the HS glycan sequence and sulfation pattern drive ligand binding specificity.

Furthermore, the development of specific HSPG targeted therapeutic approaches is also being studied. Antibody-targeting of SDC1 has been used alone or combined with chemotherapy to treat multiple myeloma [231], and a clinical trial using CAR-T cells recognising SDC1 suggests that the treatment is safe, well-tolerable and has potential antitumour activity [232]. In the same line, in hepatocellular carcinoma, the strategies of immunotoxin and CAR-T cells against GPC 3 are showing promising results and are under clinical trials [233-235].

\subsection{Heparan Sulfate Mimetics Development and Clinical Trials \\ 5.3.1. Heparan Sulfate Mimetics Rational}

Heparin derivatives and HS mimetics are drawing great attention for developing new therapeutics for diverse diseases, from inflammation to neurodegenerative disorders and cancer [207]. HS mimetics overcome a problem known for more than half a century in Medicine related to heparin use. Heparin is an anticoagulant drug which has been widely used and remains one of the main drugs for prophylaxis and treatment of thrombosis [236]. Thrombosis is a common complication of cancer patients. The use of heparin has improved the survival rate of cancer patients [237]. The functional roles of heparin seem far more than anticoagulation, since a number of additional beneficial effects have been observed for heparin in other diseases than thrombosis [238]. However, heparin is an animalderived heterogeneous polysaccharide, therefore the potential risk of contamination and its complicated molecular structure restrict its use. Therefore, and taking in consideration the high structural similarities between heparin and HS, it was tested whether heparin interferes with HS interactions with its ligands mainly through the hamper of angiogenic growth factors, like VEGF and FGF, selectins, and HPSE $[239,240]$. Indeed, in vitro analyses have shown that heparin is able to inhibit HPSE activity [240]. Since it is important to restrict heparin anticoagulant activity, due to haemorrhagic issues, efforts were made to eliminate the anticoagulation activity by chemical modification.

Roneparstat (SST0001) was the first synthetic product based on this premise. SST0001 is a $100 \% N$-acetylated and glycol split heparin synthetic molecule [241]. The SST0001 HPSE inhibitory effect was confirmed on myeloma cell growth, and therefore, it is being evaluated for the treatment of multiple myeloma [242].

The principle of using HS mimetics is to interfere with the interactions between HS and its molecular partners (Figure 2C). There are two types of HS mimetics: (1) Synthetic saccharide-based HS assembled from a backbone sugar structure; and (2) non-sugar scaffold negatively charged with sulfates, sulfonates, carboxylates and/or phosphates [205]. SST0001 and other HS-mimicking compounds main attribution is to inhibit HPSE and compete for HS binding with several growth factors, having impact on cancer by preventing angiogenic and metastatic events $[218,243]$. In summary, HS mimetics have been shown to enhance antitumour effects, particularly when combined with standard therapies.

\subsubsection{Promising Heparan Sulfate Mimicking Molecules}

The most promissory HS mimetics that are on clinical trials are: Highly sulfated phosphosulfomannan muparfostat (PI-88) [244], 2,3-O-desulfated heparin CX-01 (ODSH) [245], SST0001 [246] and pixatimod (PG545) [214]. The latter was selected from oligosaccharidic HS mimetics of the PG500 series as the best candidate regarding cancer treatment applications [247].

PI-88 is an HPSE inhibitor and also an antagonist of HS-protein interactions. Structurally it is a phospho-mannopentaose obtained through a process of sulfation of a phospho- 
mannan complex produced by yeasts $[243,248]$. It was the first one entering clinical trials and, generally, phase I/II studies demonstrated a satisfactory pharmacodynamic profile of this mimetic that was also considered safe and well-tolerated, showing minor anticoagulant effects. As main results, PI-88 has proven to be a suitable candidate as an adjuvant for postsurgical hepatocellular carcinoma in phase II clinical trials [249,250]. Subsequently, it reached Phase III in clinical trials regarding large series of liver cancer patients after hepatectomy. In fact, it is currently waiting for approval to enter routine clinical use [250]. Patients with advanced melanoma were recruited for a Phase I and Phase III clinical trials and PI-88 activity was beneficial [251]. Overall, PI-88 showed encouraging results for melanoma, multiple myeloma, prostate and lung cancer treatment [205].

CX-01 is a low anticoagulant 2-O, 3-O desulfated heparin derived from porcine intestinal heparin retaining many anti-inflammatory properties. It has been shown to have a particular potential for acute myeloid leukaemia (AML) treatment [245]. This molecule inhibits leukemic stem cells to concentrate on the bone marrow, therefore enhancing chemotherapy treatments. CX-01 specifically binds chemokine platelet factor 4 (PF4), which is responsible for the negative regulation of megakaryopoiesis [252]. Therefore, by interfering with this process, CX-01 is able to diminish chemotherapy-induced thrombocytopenia. Phase I clinical trial on AML patients demonstrated CX-01 to be well-tolerated and more recently, it entered Phase II and showed promising results in combination with the standard chemotherapy treatment [253].

Preclinical models with SST0001 shown the effective inhibition of myeloma growth in vivo [242]. SST0001 progressed to a Phase I open-label clinical trial design to assess the safety and tolerability profile of this compound in patients with multiple myeloma [254]. Recently, SST0001 was advised for Phase II evaluation [254].

The HS-mimicking molecule with the best clinical evaluation so far is PG545 [255]. PG545 is a fully sulfated glucopyranose tetrasaccharide particularly designed with a hydrophobic 3-cholestanyl group [247,255]. The novel characteristic of this molecule is the stimulation of innate immune cell response to tumours. This stimulation is done via activation of natural killer cells [256]. Clinical trials proved PG545 as a satisfactory alternative in patients with advanced solid malignancies in which standard therapies failed [247]. Currently, PG545 is also being investigated as a potential inhibitor of the SARS-CoV-2 [257].

In addition to the role of HS as an emerging class of molecules for therapeutic strategies, HS glycan chains also constitute important cellular markers. These properties make HS important targets for vaccines development strategies [258].

\subsection{Current Heparan Sulfate-Based Biomarkers Landscape}

New biomarkers to improve cancer diagnosis are needed, thus improving patient outcomes. In contrast to RNA, DNA and protein synthesis, HS biosynthesis is not a template-driven process. Instead, as mentioned previously, HS are assembled by the activity of a series of enzymes-turning this biosynthetic pathway into a source of very distinct and specific modifications with diverse applications. The type of HSPG glycosylation was shown to affect the ability of immune cells to infiltrate tumour tissues and engage in the immune response [259]. In addition to the critical roles in multiple aspects of tumour biology, described in the previous sections, HSPGs also have value for clinical diagnosis and prognosis in various cancer types. The alteration of GAG abundances is reflected in body fluids (like blood and/or urine), and the HS levels in plasma can, therefore, predict patient's prognosis [260]. For all these attributes, HS and HSPGs are promising new biomarkers in cancer since their recognition by other molecules is based in high affinity and exquisite specificity. It is imperative to discriminate among related isomers the specific glycan-binding partner. The development of more sophisticated equipment and techniques have been critical to surpass these limitations. Recently, using Raman micro-spectroscopy it was possible to determine unique and discrete HS profiles of individual live cells, which can 
be of value for clinical screening purposes. This method can be utilised for identifying specific molecular signatures of HS and HSPGs as markers of cancer [261].

GPCs have been receiving great attention from the research community as promising biomarkers [262]. GPC1 is overexpressed in several cancer types [263,264]. GPC1 can be detected in the urine of prostate cancer patients [265]. Further, GPC1 was shown to associate with the dissemination levels of glioblastoma [148]. The abundance of GPC1 also positively correlates with disease severity of pancreatic cancer patients, independently on surgical treatment, suggesting that GPC1 is a surgery-independent diagnostic biomarker $[263,266]$. Recently, GPC 3 was pointed as a promising candidate for hepatocellular carcinoma diagnosis and immunotherapy, as previously described [267]. Similarly, GPC6 was identified as a putative biomarker for the metastatic progression of cutaneous melanoma, since it is possible to track higher levels of GPC6 in melanoma samples when compared with normal melanocytes [268].

The biological features of EVs, such as long half-life and physical resistance properties, make EVs a unique source of biomarkers [167]. Particularly, the identification of specific PGs in EVs secreted by cancer cells has demonstrated their potential as biomarkers for minimally invasive diagnosis. Two important examples are GPC1 in pancreatic cancer [266] and SDC1 in glioma [269]. Both HSPGs were detected in EVs isolated from patients' plasma, supporting the concept of a minimally invasive biomarker for patients' stratification. GPC1 was proven to distinguish healthy individuals and patients with a benign pancreatic disease from patients with early- and late-stage pancreatic cancer. Moreover, GPC1-positive EV levels correlated with tumour burden and the patients' survival and were shown as a prognostic marker superior to CA 19-9, the serum biomarker currently employed in pancreatic cancer screening [266]. SDC1 was shown to discriminate between highgrade glioblastoma multiforme and low-grade glioma, and therefore, with the potential to improve the management of brain tumour patients that present high risk of surgeryassociated complications [269].

The recent development of EV analysis platforms based on microfluidics technologies holds promise for the development of high sensitivity and high-throughput assays of EVs analysis with clinical diagnosis purpose [270].

\section{Conclusions and Future Challenges}

The emerging HSPGs biological functions have largely surpassed their classical role as cellular co-receptors and have highlighted HSPGs as main maestros of cancer cell communication and ECM structuring. The HSPGs cellular interactome is vast and is finetuned by the biochemical and structural features of the HS chains. HS lack a template for its biosynthesis, and their structural features result from the dynamic cellular GAGosylation pathways that include the sequential, and in some cases competitive, action of specific enzymes, which may associate to form supramolecular complexes [25]. The structural efforts to produce chemically defined HS oligosaccharides [271] have been crucial for the identification of the molecular determinants of enzymatic activity. However, we are still far from fully understanding the complete regulation of HS structural and functional diversity in health and particularly in cancer.

The recent developments in glycosaminoglycanomics, namely, on the analytical techniques for GAGs profiling in cells and clinical samples (tissues and biological fluids), together with the establishment of computational tools for mining GAG-protein interactions and creation of databases, are contributing to significantly improve the knowledge on the human glycosaminoglycome [19,272]. Moreover, the integration of HS structural features and expression with proteomic and transcriptomic analysis will be crucial for further elucidating HS-ligand interactions and unravel HS structure features associated with specific biological functions [273]. Particularly relevant would be the integration of data on relative abundance and structural features of HS for the definition of cancer-specific profiles. Therefore, it is important to apply the most recent GAG analytical approaches to well characterised clinical samples to identify HS signatures that are cancer-specific. To suc- 
cessfully achieve this aim, it is key to incorporate also knowledge on the dysregulation of HS biosynthetic and post-synthetic modification pathways, as well as on the functional redundancy of different PG core protein families in cancer.

The multidimensional roles of HS and HSPGs in different steps of cancer progression have propelled the development of HS-targeted strategies for cancer diagnosis and treatment [200]. Indeed, in this new period of precision oncology, HS GAGs are currently (un)expectedly emerging as allies to improve cancer clinical management by their potential to detect cancer in early stages, allowing an accurate diagnosis, disease monitoring, patients stratification and improve prognosis.

The HSPGs role in regulating EV release, cargo and uptake is well defined [160], but the implications of altered PG expression and glycosylation features in EV biodistribution and metastasis tropism remain to be discovered. It has become highly relevant to understand the impact of HSPG remodelling, both at the level of the glycan structures and core protein expression, in cancer EV-mediated signalling. Understanding the glycosylation modifications involved in EV-cell interaction and cellular uptake is of major relevance for developing therapeutic approaches targeting EV-HSPG interactions as novel cancer treatment strategies.

Author Contributions: Conceptualization I.F.-R., J.P., C.M., and A.M.; writing-original draft preparation I.F.-R., J.P., C.M., J.S.-A. and A.M.; Figures preparation I.F.-R., J.P. and C.M.; writing-review G.M., C.A.R., A.M.; funding acquisition, A.M. All authors have read and agreed to the published version of the manuscript.

Funding: This work was financed by FEDER-Fundo Europeu de Desenvolvimento Regional funds through the COMPETE 2020-Operacional Programme for Competitiveness and Internationalization (POCI), Portugal 2020, and by Portuguese funds through FCT-Fundação para a Ciência e a Tecnologia/ Ministério da Ciência, Tecnologia e Inovação in the framework of the project "Institute for Research and Innovation in Health Sciences" (POCI-01-0145-FEDER-007274) and by the grant POCI-01-0145FEDER-028489 (to A.M.). J.P. and C.M. are funded by FCT PhD scholarships SFRH/BD/137319/2018 and 2020.06412.BD, respectively. The APC was funded by FCT grant POCI-01-0145-FEDER-028489. The authors acknowledge the support of the COST Action CA18103 INNOGLY.

Data Availability Statement: Not applicable.

Conflicts of Interest: The authors declare no conflict of interest. The funders had no role in the design and writing of the manuscript, or in the decision to publish.

\section{References}

1. Bishop, J.R.; Schuksz, M.; Esko, J.D. Heparan sulphate proteoglycans fine-tune mammalian physiology. Nat. Cell Biol. 2007, 446, 1030-1037. [CrossRef] [PubMed]

2. Chang, Y.-C.; Wang, Z.; Flax, L.A.; Xu, D.; Esko, J.D.; Nizet, V.; Baron, M.J. Glycosaminoglycan Binding Facilitates Entry of a Bacterial Pathogen into Central Nervous Systems. PLoS Pathog. 2011, 7, e1002082. [CrossRef] [PubMed]

3. Esko, J.D.; Linhardt, R.J. Proteins That Bind Sulfated Glycosaminoglycans. In Essentials of Glycobiology; Varki, A., Cummings, R.D., Esko, J.D., Stanley, P., Hart, G.W., Aebi, M., Darvill, A.G., Kinoshita, T., Packer, N.H., Eds.; Cold Spring Harbor Laboratory Press: Cold Spring Harbor, NY, USA, 2015; pp. 493-502.

4. Esko, J.D.; Selleck, S.B. Order Out of Chaos: Assembly of Ligand Binding Sites in Heparan Sulfate. Annu. Rev. Biochem. 2002, 71, 435-471. [CrossRef] [PubMed]

5. Nizet, V.; Esko, J.D. Bacterial and Viral Infections. In Essentials of Glycobiology; Varki, A., Cummings, R.D., Esko, J.D., Freeze, H.H., Stanley, P., Bertozzi, C.R., Hart, G.W., Etzler, M.E., Eds.; Cold Spring Harbor Laboratory Press: Cold Spring Harbor, NY, USA, 2009.

6. Li, J.-P.; Kusche-Gullberg, M. Heparan Sulfate: Biosynthesis, Structure, and Function. Int. Rev. Cell Mol. Biol. 2016, 325, 215-273. [CrossRef] [PubMed]

7. Afratis, N.; Gialeli, C.; Nikitovic, D.; Tsegenidis, T.; Karousou, E.; Theocharis, A.D.; Pavão, M.S.; Tzanakakis, G.N.; Karamanos, N.K. Glycosaminoglycans: Key players in cancer cell biology and treatment. FEBS J. 2012, 279, 1177-1197. [CrossRef]

8. Lindahl, U.; Couchman, J.; Kimata, K.; Esko, J.D. Proteoglycans and Sulfated Glycosaminoglycans. In Essentials of Glycobiology, 3rd ed.; Cold Spring Harbor Laboratory Press: Cold Spring Harbor, NY, USA, 2015.

9. Couchman, J.R.; Multhaupt, H.; Sanderson, R.D. Recent Insights into Cell Surface Heparan Sulphate Proteoglycans and Cancer. F1000Research 2016, 5, 1541. [CrossRef] 
10. Ghossoub, R.; Chéry, M.; Audebert, S.; Leblanc, R.; Egea-Jimenez, A.L.; Lembo, F.; Mammar, S.; Le Dez, F.; Camoin, L.; Borg, J.-P.; et al. Tetraspanin-6 negatively regulates exosome production. Proc. Natl. Acad. Sci. USA 2020, 117, $5913-5922$. [CrossRef]

11. Lawrence, R.; Brown, J.R.; Lorey, F.; Dickson, P.I.; Crawford, B.E.; Esko, J.D. Glycan-based biomarkers for mucopolysaccharidoses. Mol. Genet. Metab. 2014, 111, 73-83. [CrossRef]

12. Da Costa, D.S.; Reis, R.L.; Pashkuleva, I. Sulfation of Glycosaminoglycans and Its Implications in Human Health and Disorders. Annu. Rev. Biomed. Eng. 2017, 19, 1-26. [CrossRef]

13. Brown, J.R.; Crawford, B.E.; Esko, J.D. Glycan Antagonists and Inhibitors: A Fount for Drug Discovery. Crit. Rev. Biochem. Mol. Biol. 2007, 42, 481-515. [CrossRef]

14. Köwitsch, A.; Zhou, G.; Groth, T. Medical application of glycosaminoglycans: A review. J. Tissue Eng. Regen. Med. 2018, 12, e23-e41. [CrossRef] [PubMed]

15. Lanzi, C.; Yates, E.A.; Cassinelli, G. Editorial: Heparan Sulfate Proteoglycans and Their Endogenous Modifying Enzymes: Cancer Players, Biomarkers and Therapeutic Targets. Front. Oncol. 2020, 10, 195. [CrossRef]

16. Vitale, D.; Katakam, S.K.; Greve, B.; Jang, B.; Oh, E.; Alaniz, L.; Gotte, M. Proteoglycans and glycosaminoglycans as regulators of cancer stem cell function and therapeutic resistance. FEBS J. 2019, 286, 2870-2882. [CrossRef] [PubMed]

17. Hassan, N.; Greve, B.; Espinoza-Sánchez, N.A.; Gotte, M. Cell-surface heparan sulfate proteoglycans as multifunctional integrators of signaling in cancer. Cell. Signal. 2020, 77, 109822. [CrossRef] [PubMed]

18. Raman, K.; Kuberan, B. Chemical Tumor Biology of Heparan Sulfate Proteoglycans. Curr. Chem. Biol. 2010, 4, 20-31. [CrossRef] [PubMed]

19. Ricard-Blum, S.; Lisacek, F. Glycosaminoglycanomics: Where we are. Glycoconj. J. 2016, 34, 339-349. [CrossRef] [PubMed]

20. Compagnon, I.; Schindler, B.; Renois-Predelus, G.; Daniel, R. Lasers and ion mobility: New additions to the glycosaminoglycanomics toolkit. Curr. Opin. Struct. Biol. 2018, 50, 171-180. [CrossRef]

21. Bonnans, C.; Chou, J.; Werb, Z. Remodelling the extracellular matrix in development and disease. Nat. Rev. Mol. Cell Biol. 2014 15, 786-801. [CrossRef]

22. Theocharis, A.D.; Skandalis, S.S.; Gialeli, C.; Karamanos, N.K. Extracellular matrix structure. Adv. Drug Deliv. Rev. 2016, 97, 4-27. [CrossRef]

23. Song, H.H.; Filmus, J. The role of glypicans in mammalian development. Biochim. Biophys. Acta Gen. Subj. 2002, 1573, 241-246. [CrossRef]

24. Iozzo, R.V.; Schaefer, L. Proteoglycan form and function: A comprehensive nomenclature of proteoglycans. Matrix Biol. J. Int. Soc. Matrix Biol. 2015, 42, 11-55. [CrossRef] [PubMed]

25. Annaval, T.; Wild, R.; Crétinon, Y.; Sadir, R.; Vivès, R.R.; Lortat-Jacob, H. Heparan Sulfate Proteoglycans Biosynthesis and Post Synthesis Mechanisms Combine Few Enzymes and Few Core Proteins to Generate Extensive Structural and Functional Diversity. Molecules 2020, 25, 4215. [CrossRef] [PubMed]

26. Rong, J.; Habuchi, H.; Kimata, K.; Lindahl, A.U.; Kusche-Gullberg, M. Substrate Specificity of the Heparan Sulfate Hexuronic Acid 2-O-Sulfotransferase. Biochemistry 2001, 40, 5548-5555. [CrossRef] [PubMed]

27. Koike, T.; Izumikawa, T.; Tamura, J.-I.; Kitagawa, H. FAM20B is a kinase that phosphorylates xylose in the glycosaminoglycanprotein linkage region. Biochem. J. 2009, 421, 157-162. [CrossRef] [PubMed]

28. Wen, J.; Xiao, J.; Rahdar, M.; Choudhury, B.P.; Cui, J.; Taylor, G.S.; Esko, J.D.; Dixon, J.E. Xylose phosphorylation functions as a molecular switch to regulate proteoglycan biosynthesis. Proc. Natl. Acad. Sci. USA 2014, 111, 15723-15728. [CrossRef]

29. Koike, T.; Izumikawa, T.; Sato, B.; Kitagawa, H. Identification of Phosphatase That Dephosphorylates Xylose in the Glycosaminoglycan-Protein Linkage Region of Proteoglycans. J. Biol. Chem. 2014, 289, 6695-6708. [CrossRef]

30. Chen, Y.-H.; Narimatsu, Y.; Clausen, T.M.; Gomes, C.; Karlsson, R.; Steentoff, C.; Spliid, C.B.; Gustavsson, T.; Salanti, A.; Persson, A.; et al. The GAGOme: A cell-based library of displayed glycosaminoglycans. Nat. Methods 2018, 15, 881-888. [CrossRef]

31. McCormick, C.; Duncan, G.; Goutsos, K.T.; Tufaro, F. The putative tumor suppressors EXT1 and EXT2 form a stable complex that accumulates in the Golgi apparatus and catalyzes the synthesis of heparan sulfate. Proc. Natl. Acad. Sci. USA 2000, 97, 668-673. [CrossRef]

32. Kim, B.-T.; Kitagawa, H.; Tamura, J.-I.; Saito, T.; Kusche-Gullberg, M.; Lindahl, U.; Sugahara, K. Human tumor suppressor EXT gene family members EXTL1 and EXTL3 encode 1,4- N-acetylglucosaminyltransferases that likely are involved in heparan sulfate/ heparin biosynthesis. Proc. Natl. Acad. Sci. USA 2001, 98, 7176-7181. [CrossRef]

33. Kitagawa, H.; Shimakawa, H.; Sugahara, K. The Tumor Suppressor EXT-like GeneEXTL2Encodes an $\alpha 1$, 4-NAcetylhexosaminyltransferase That TransfersN-Acetylgalactosamine andN-Acetylglucosamine to the Common GlycosaminoglycanProtein Linkage Region. J. Biol. Chem. 1999, 274, 13933-13937. [CrossRef]

34. Kim, B.-T.; Kitagawa, H.; Tanaka, J.; Tamura, J.-I.; Sugahara, K. In Vitro Heparan Sulfate Polymerization. J. Biol. Chem. 2003, 278, 41618-41623. [CrossRef] [PubMed]

35. Takahashi, I.; Noguchi, N.; Nata, K.; Yamada, S.; Kaneiwa, T.; Mizumoto, S.; Ikeda, T.; Sugihara, K.; Asano, M.; Yoshikawa, T.; et al. Important role of heparan sulfate in postnatal islet growth and insulin secretion. Biochem. Biophys. Res. Commun. 2009, 383, 113-118. [CrossRef] [PubMed] 
36. Lee, J.-S.; von der Hardt, S.; Rusch, M.A.; Stringer, S.E.; Stickney, H.L.; Talbot, W.S.; Geisler, R.; Nusslein-Volhard, C.; Selleck, S.B.; Chien, C.-B.; et al. Axon Sorting in the Optic Tract Requires HSPG Synthesis by ext2 (dackel) and extl3 (boxer). Neuron 2004, 44, 947-960. [CrossRef] [PubMed]

37. Nadanaka, S.; Zhou, S.; Kagiyama, S.; Shoji, N.; Sugahara, K.; Sugihara, K.; Asano, M.; Kitagawa, H. EXTL2, a Member of theEXTFamily of Tumor Suppressors, Controls Glycosaminoglycan Biosynthesis in a Xylose Kinase-dependent Manner. J. Biol. Chem. 2013, 288, 9321-9333. [CrossRef] [PubMed]

38. Purnomo, E.; Emoto, N.; Nugrahaningsih, D.A.A.; Nakayama, K.; Yagi, K.; Heiden, S.; Nadanaka, S.; Kitagawa, H.; Hirata, K. Glycosaminoglycan Overproduction in the Aorta Increases Aortic Calcification in Murine Chronic Kidney Disease. J. Am. Hear. Assoc. 2013, 2, e000405. [CrossRef] [PubMed]

39. El Masri, R.; Seffouh, A.; Lortat-Jacob, H.; Vivès, R.R. The "in and out" of glucosamine 6-O-sulfation: The 6th sense of heparan sulfate. Glycoconj. J. 2016, 34, 285-298. [CrossRef]

40. Maccarana, M.; Sakura, Y.; Tawada, A.; Yoshida, K.; Lindahl, U. Domain Structure of Heparan Sulfates from Bovine Organs. J. Biol. Chem. 1996, 271, 17804-17810. [CrossRef]

41. Warda, M.; Toida, T.; Zhang, F.; Sun, P.; Munoz, E.; Xie, J.; Linhardt, R.J. Isolation and characterization of heparan sulfate from various murine tissues. Glycoconj. J. 2006, 23, 555-563. [CrossRef]

42. Nigam, S.K.; Bush, K.T. Growth factor-heparan sulfate "switches" regulating stages of branching morphogenesis. Pediatr. Nephrol. 2014, 29, 727-735. [CrossRef]

43. Garner, O.B.; Bush, K.T.; Nigam, K.B.; Yamaguchi, Y.; Xu, D.; Esko, J.D.; Nigam, S.K. Stage-dependent regulation of mammary ductal branching by heparan sulfate and HGF-cMet signaling. Dev. Biol. 2011, 355, 394-403. [CrossRef]

44. Shah, M.M.; Sakurai, H.; Gallegos, T.F.; Sweeney, D.E.; Bush, K.T.; Esko, J.D.; Nigam, S.K. Growth factor-dependent branching of the ureteric bud is modulated by selective 6-O sulfation of heparan sulfate. Dev. Biol. 2011, 356, 19-27. [CrossRef] [PubMed]

45. Theocharis, A.D.; Vynios, D.H.; Papageorgakopoulou, N.; Skandalis, S.S.; A Theocharis, D. Altered content composition and structure of glycosaminoglycans and proteoglycans in gastric carcinoma. Int. J. Biochem. Cell Biol. 2003, 35, 376-390. [CrossRef]

46. Fernandez-Vega, I.; García-Suárez, O.; Crespo, A.; Castañón, S.; Menéndez, P.; Astudillo, A.; Quirós, L.M. Specific genes involved in synthesis and editing of heparan sulfate proteoglycans show altered expression patterns in breast cancer. BMC Cancer 2013, 13, 24. [CrossRef] [PubMed]

47. Xu, D.; Esko, J.D. Demystifying Heparan Sulfate-Protein Interactions. Annu. Rev. Biochem. 2014, 83, 129-157. [CrossRef] [PubMed]

48. Mitsou, I.; Multhaupt, H.A.; Couchman, J.R. Proteoglycans, ion channels and cell-matrix adhesion. Biochem. J. 2017, 474, 1965-1979. [CrossRef]

49. Clausen, T.M.; Sandoval, D.R.; Spliid, C.B.; Pihl, J.; Perrett, H.R.; Painter, C.D.; Narayanan, A.; Majowicz, S.A.; Kwong, E.M.; McVicar, R.N.; et al. SARS-CoV-2 Infection Depends on Cellular Heparan Sulfate and ACE2. Cell 2020, 183, 1043-1057.e15. [CrossRef]

50. Brandhorst, T.T.; Roy, R.; Wüthrich, M.; Nanjappa, S.; Filutowicz, H.; Galles, K.; Tonelli, M.; McCaslin, D.R.; A Satyshur, K.; Klein, B.S. Structure and Function of a Fungal Adhesin that Binds Heparin and Mimics Thrombospondin-1 by Blocking T Cell Activation and Effector Function. PLoS Pathog. 2013, 9, e1003464. [CrossRef]

51. Liu, J.; Thorp, S.C. Cell surface heparan sulfate and its roles in assisting viral infections. Med. Res. Rev. 2002, 22, 1-25. [CrossRef]

52. Couchman, J.R.; Gopal, S.; Lim, H.C.; Nørgaard, S.; Multhaupt, H.A. Fell-Muir Lecture: Syndecans: From peripheral coreceptors to mainstream regulators of cell behaviour. Int. J. Exp. Pathol. 2014, 96, 1-10. [CrossRef]

53. Yamaguchi, Y. Heparan sulfate proteoglycans in the nervous system: Their diverse roles in neurogenesis, axon guidance, and synaptogenesis. Semin. Cell Dev. Biol. 2001, 12, 99-106. [CrossRef]

54. Koziel, L.; Kunath, M.; Kelly, O.G.; Vortkamp, A. Ext1-Dependent Heparan Sulfate Regulates the Range of Ihh Signaling during Endochondral Ossification. Dev. Cell 2004, 6, 801-813. [CrossRef] [PubMed]

55. Rodgers, K.D.; Antonio, J.D.S.; Jacenko, O. Heparan sulfate proteoglycans: A GAGgle of skeletal-hematopoietic regulators. Dev. Dyn. 2008, 237, 2622-2642. [CrossRef] [PubMed]

56. Gopal, S.; Søgaard, P.; Multhaupt, H.A.; Pataki, C.; Okina, E.; Xian, X.; Pedersen, M.E.; Stevens, T.; Griesbeck, O.; Park, P.W.; et al. Transmembrane proteoglycans control stretch-activated channels to set cytosolic calcium levels. J. Cell Biol. 2015, 210, 1199-1211. [CrossRef] [PubMed]

57. MacArthur, J.M.; Bishop, J.R.; Stanford, K.I.; Wang, L.; Bensadoun, A.; Witztum, J.L.; Esko, J.D. Liver heparan sulfate proteoglycans mediate clearance of triglyceride-rich lipoproteins independently of LDL receptor family members. J. Clin. Investig. 2007, 117, 153-164. [CrossRef]

58. Christianson, H.C.; Belting, M. Heparan sulfate proteoglycan as a cell-surface endocytosis receptor. Matrix Biol. 2014, 35, 51-55. [CrossRef]

59. Al-Haideri, M.; Goldberg, I.J.; Galeano, N.F.; Gleeson, A.; Vogel, T.; Gorecki, M.; Sturley, S.L.; Deckelbaum, R.J. Heparan Sulfate Proteoglycan-Mediated Uptake of Apolipoprotein E-Triglyceride-Rich Lipoprotein Particles: A Major Pathway at Physiological Particle Concentrations. Biochemistry 1997, 36, 12766-12772. [CrossRef]

60. Menard, J.A.; Cerezo-Magaña, M.; Belting, M. Functional role of extracellular vesicles and lipoproteins in the tumour microenvironment. Philos. Trans. R. Soc. B Biol. Sci. 2018, 373, 20160480. [CrossRef]

61. Collins, L.E.; Troeberg, L. Heparan sulfate as a regulator of inflammation and immunity. J. Leukoc. Biol. 2019, 105, 81-92. [CrossRef] 
62. Reine, T.M.; Kusche-Gullberg, M.; Feta, A.; Jenssen, T.; Kolset, S.O. Heparan sulfate expression is affected by inflammatory stimuli in primary human endothelial cells. Glycoconj. J. 2011, 29, 67-76. [CrossRef]

63. Massena, S.; Christoffersson, G.; Hjertström, E.; Zcharia, E.; Vlodavsky, I.; Ausmees, N.; Rolny, C.; Li, J.-P.; Phillipson, M. A chemotactic gradient sequestered on endothelial heparan sulfate induces directional intraluminal crawling of neutrophils. Blood 2010, 116, 1924-1931. [CrossRef]

64. Celie, J.W.A.M. Heparan sulfate proteoglycans in extravasation: Assisting leukocyte guidance. Front. Biosci. 2009, 14, 4932-4949. [CrossRef] [PubMed]

65. El Masri, R.; Crétinon, Y.; Gout, E.; Vivès, R.R. HS and Inflammation: A Potential Playground for the Sulfs? Front. Immunol. 2020, 11, 570. [CrossRef] [PubMed]

66. Iozzo, R.V. Basement membrane proteoglycans: From cellar to ceiling. Nat. Rev. Mol. Cell Biol. 2005, 6, 646-656. [CrossRef]

67. Farach-Carson, M.C.; Warren, C.R.; Harrington, D.A.; Carson, D.D. Border patrol: Insights into the unique role of perlecan/heparan sulfate proteoglycan 2 at cell and tissue borders. Matrix Biol. 2014, 34, 64-79. [CrossRef] [PubMed]

68. García, B.; Merayo-Lloves, J.; Martin, C.; Alcalde, I.; Quirós, L.M.; Vázquez, F. Surface Proteoglycans as Mediators in Bacterial Pathogens Infections. Front. Microbiol. 2016, 7, 220. [CrossRef] [PubMed]

69. Maciej-Hulme, M.L.; Skidmore, M.A.; Price, H.P. The role of heparan sulfate in host macrophage infection by Leishmania species. Biochem. Soc. Trans. 2018, 46, 789-796. [CrossRef]

70. Armistead, J.S.; Wilson, I.B.; van Kuppevelt, T.H.; Dinglasan, R.R. A role for heparan sulfate proteoglycans in Plasmodium falciparum sporozoite invasion of anopheline mosquito salivary glands. Biochem. J. 2011, 438, 475-483. [CrossRef]

71. Rajan, A.; Robertson, M.J.; Carter, H.E.; Poole, N.M.; Clark, J.; Green, S.I.; Criss, Z.K.; Zhao, B.; Karandikar, U.; Xing, Y.; et al. Enteroaggregative E. coli Adherence to Human Heparan Sulfate Proteoglycans Drives Segment and Host Specific Responses to Infection. PLoS Pathog. 2020, 16, e1008851. [CrossRef]

72. Paulsson, M.; Su, Y.-C.; Ringwood, T.; Uddén, F.; Riesbeck, K. Pseudomonas aeruginosa uses multiple receptors for adherence to laminin during infection of the respiratory tract and skin wounds. Sci. Rep. 2019, 9, 18168. [CrossRef]

73. Lin, Y.-P.; Li, L.; Zhang, F.; Linhardt, R.J. Borrelia burgdorferi glycosaminoglycan-binding proteins: A potential target for new therapeutics against Lyme disease. Microbiol. 2017, 163, 1759-1766. [CrossRef]

74. Menozzi, F.D.; Reddy, V.M.; Cayet, D.; Raze, D.; Debrie, A.-S.; Dehouck, M.-P.; Cecchelli, R.; Locht, C. Mycobacterium tuberculosis heparin-binding haemagglutinin adhesin (HBHA) triggers receptor-mediated transcytosis without altering the integrity of tight junctions. Microbes Infect. 2006, 8, 1-9. [CrossRef] [PubMed]

75. Agelidis, A.; Shukla, D. Heparanase, Heparan Sulfate and Viral Infection. Adv. Exp. Med. Biol. 2020, 1221, 759-770. [CrossRef] [PubMed]

76. Connell, B.J.; Lortat-Jacob, H. Human Immunodeficiency Virus and Heparan Sulfate: From Attachment to Entry Inhibition. Front. Immunol. 2013, 4, 385. [CrossRef] [PubMed]

77. Martino, C.; Kellman, B.P.; Sandoval, D.R.; Clausen, T.M.; Marotz, C.A.; Song, S.J.; Wandro, S.; Zaramela, L.S.; Salido Benitez, R.A.; Zhu, Q.; et al. Bacterial modification of the host glycosaminoglycan heparan sulfate modulates SARS-CoV-2 infectivity. bioRxiv 2020.

78. Liu, L.; Chopra, P.; Li, X.; Wolfert, M.A.; Tompkins, S.M.; Boons, G.J. SARS-CoV-2 spike protein binds heparan sulfate in a lengthand sequence-dependent manner. bioRxiv 2020.

79. Lan, J.; Ge, J.; Yu, J.; Shan, S.; Zhou, H.; Fan, S.; Zhang, Q.; Shi, X.; Wang, Q.; Zhang, L.; et al. Structure of the SARS-CoV-2 spike receptor-binding domain bound to the ACE2 receptor. Nature 2020, 581, 215-220. [CrossRef]

80. Shang, J.; Ye, G.; Shi, K.; Wan, Y.; Luo, C.; Aihara, H.; Geng, Q.; Auerbach, A.; Li, F. Structural basis of receptor recognition by SARS-CoV-2. Nat. Cell Biol. 2020, 581, 221-224. [CrossRef]

81. Kwon, P.S.; Oh, H.; Kwon, S.-J.; Jin, W.; Zhang, F.; Fraser, K.; Hong, J.J.; Linhardt, R.J.; Dordick, J.S. Sulfated polysaccharides effectively inhibit SARS-CoV-2 in vitro. Cell Discov. 2020, 6, 1-4. [CrossRef]

82. Park, P.W. Glycosaminoglycans and infection. Front. Biosci. 2016, 21, 1260-1277. [CrossRef]

83. Hanahan, D.; Coussens, L.M. Accessories to the crime: Functions of cells recruited to the tumor microenvironment. Cancer Cell 2012, 21, 309-322. [CrossRef]

84. Pickup, M.W.; Mouw, J.K.; Weaver, V.M. The extracellular matrix modulates the hallmarks of cancer. EMBO Rep. 2014, 15, 1243-1253. [CrossRef] [PubMed]

85. Hanahan, D.; Weinberg, R.A. Hallmarks of Cancer: The Next Generation. Cell 2011, 144, 646-674. [CrossRef] [PubMed]

86. Pinho, S.S.; Reis, C.A. Glycosylation in cancer: Mechanisms and clinical implications. Nat. Rev. Cancer 2015, 15, 540-555. [CrossRef]

87. Mereiter, S.; Balmaña, M.; Campos, D.; Gomes, J.; Reis, C.A. Glycosylation in the Era of Cancer-Targeted Therapy: Where Are We Heading? Cancer Cell 2019, 36, 6-16. [CrossRef] [PubMed]

88. Knelson, E.H.; Nee, J.C.; Blobe, G.C. Heparan sulfate signaling in cancer. Trends Biochem. Sci. 2014, 39, 277-288. [CrossRef]

89. Derksen, P.W.B.; Keehnen, R.M.J.; Evers, L.M.; van Oers, M.H.J.; Spaargaren, M.; Pals, S.T. Cell surface proteoglycan syndecan1 mediates hepatocyte growth factor binding and promotes Met signaling in multiple myeloma. Blood 2002, 99, 1405-1410. [CrossRef]

90. Ren, Z.; van Andel, H.; de Lau, W.; Hartholt, R.B.; Maurice, M.M.; Clevers, H.; Kersten, M.J.; Spaargaren, M.; Pals, S.T. Syndecan-1 promotes Wnt/ $\beta$-catenin signaling in multiple myeloma by presenting Wnts and R-spondins. Blood 2018, 131, 982-994. [CrossRef] 
91. Nagarajan, A.; Malvi, P.; Wajapeyee, N. Heparan Sulfate and Heparan Sulfate Proteoglycans in Cancer Initiation and Progression. Front. Endocrinol. 2018, 9, 483. [CrossRef]

92. Suhovskih, A.V.; Domanitskaya, N.V.; Tsidulko, A.Y.; Prudnikova, T.Y.; I Kashuba, V.; Grigorieva, E.V. Tissue-specificity of heparan sulfate biosynthetic machinery in cancer. Cell Adhes. Migr. 2015, 9, 452-459. [CrossRef]

93. Crespo, A.; García-Suárez, O.; Fernandez-Vega, I.; Solis-Hernandez, M.P.; García, B.; Castañón, S.; Quirós, L.M. Heparan sulfate proteoglycans undergo differential expression alterations in left sided colorectal cancer, depending on their metastatic character. BMC Cancer 2018, 18, 687. [CrossRef]

94. Fernandez-Vega, I.; García-Suárez, O.; García, B.; Crespo, A.; Astudillo, A.; Quirós, L.M. Heparan sulfate proteoglycans undergo differential expression alterations in right sided colorectal cancer, depending on their metastatic character. BMC Cancer 2015, 15, 742. [CrossRef] [PubMed]

95. Sembajwe, L.F.; Katta, K.; Grønning, M.; Kusche-Gullberg, M. The exostosin family of glycosyltransferases: mRNA expression profiles and heparan sulphate structure in human breast carcinoma cell lines. Biosci. Rep. 2018, 38. [CrossRef] [PubMed]

96. Cole, C.L.; Rushton, G.; Jayson, G.C.; Avizienyte, E. Ovarian Cancer Cell Heparan Sulfate 6-O-Sulfotransferases Regulate an Angiogenic Program Induced by Heparin-binding Epidermal Growth Factor (EGF)-like Growth Factor/EGF Receptor Signaling. J. Biol. Chem. 2014, 289, 10488-10501. [CrossRef] [PubMed]

97. Hwang, J.-A.; Kim, Y.; Hong, S.-H.; Lee, J.; Cho, Y.G.; Han, J.-Y.; Kim, Y.-H.; Han, J.; Shim, Y.M.; Lee, Y.-S.; et al. Epigenetic Inactivation of Heparan Sulfate (Glucosamine) 3-O-Sulfotransferase 2 in Lung Cancer and Its Role in Tumorigenesis. PLoS ONE 2013, 8, e79634. [CrossRef]

98. Chen, Z.; Fan, J.-Q.; Li, J.; Li, Q.-S.; Yan, Z.; Jia, X.-K.; Liu, W.-D.; Wei, L.-J.; Zhang, F.-Z.; Gao, H.; et al. Promoter hypermethylation correlates with theHsulf-1silencing in human breast and gastric cancer. Int. J. Cancer 2008, 124, 739-744. [CrossRef]

99. Li, J.; Mo, M.-L.; Chen, Z.; Yang, J.; Li, Q.-S.; Wang, D.-J.; Zhang, H.; Ye, Y.; Xu, J.-P.; Li, H.; et al. HSulf-1 inhibits cell proliferation and invasion in human gastric cancer. Cancer Sci. 2011, 102, 1815-1821. [CrossRef]

100. Lai, J.; Sandhu, D.S.; Yu, C.; Han, T.; Moser, C.D.; Jackson, K.K.; Guerrero, R.B.; Aderca, I.; Isomoto, H.; Garrity-Park, M.M.; et al. Sulfatase 2 up-regulates glypican 3, promotes fibroblast growth factor signaling, and decreases survival in hepatocellular carcinoma. Hepatology 2008, 47, 1211-1222. [CrossRef]

101. Nadir, Y.; Brenner, B. Heparanase multiple effects in cancer. Thromb. Res. 2014, 133, S90-S94. [CrossRef]

102. Vlodavsky, I.; Ilan, N.; Sanderson, R.D. Forty Years of Basic and Translational Heparanase Research. Adv. Exp. Med. Biol. 2020, 1221, 3-59. [CrossRef]

103. Barash, U.; Cohen-Kaplan, V.; Arvatz, G.; Gingis-Velitski, S.; Levy-Adam, F.; Nativ, O.; Shemesh, R.; Ayalon-Sofer, M.; Ilan, N.; Vlodavsky, I. A novel human heparanase splice variant, T5, endowed with protumorigenic characteristics. FASEB J. 2009, 24, 1239-1248. [CrossRef]

104. Ilan, N.; Elkin, M.; Vlodavsky, I. Regulation, function and clinical significance of heparanase in cancer metastasis and angiogenesis. Int. J. Biochem. Cell Biol. 2006, 38, 2018-2039. [CrossRef] [PubMed]

105. Sanderson, R.D.; Iozzo, R.V. Targeting heparanase for cancer therapy at the tumor-matrix interface. Matrix Biol. 2012, 31, 283-284. [CrossRef] [PubMed]

106. Zhang, L.; Ngo, J.A.; Wetzel, M.D.; Marchetti, D. Heparanase mediates a novel mechanism in lapatinib-resistant brain metastatic breast cancer. Neoplasia 2015, 17, 101-113. [CrossRef] [PubMed]

107. Alishekevitz, D.; Gingis-Velitski, S.; Kaidar-Person, O.; Gutter-Kapon, L.; Scherer, S.D.; Raviv, Z.; Merquiol, E.; Ben-Nun, Y.; Miller, V.; Rachman-Tzemah, C.; et al. Macrophage-Induced Lymphangiogenesis and Metastasis following Paclitaxel Chemotherapy Is Regulated by VEGFR3. Cell Rep. 2016, 17, 1344-1356. [CrossRef] [PubMed]

108. Ilan, N.; Shteingauz, A.; Vlodavsky, I. Function from within: Autophagy induction by HPSE/heparanase-new possibilities for intervention. Autophagy 2015, 11, 2387-2389. [CrossRef] [PubMed]

109. Singh, S.S.; Vats, S.; Chia, A.Y.-Q.; Tan, T.Z.; Deng, S.; Ong, M.S.; Arfuso, F.; Yap, C.T.; Goh, B.C.; Sethi, G.; et al. Dual role of autophagy in hallmarks of cancer. Oncogene 2018, 37, 1142-1158. [CrossRef]

110. Shteingauz, A.; Boyango, I.; Naroditsky, I.; Hammond, E.; Gruber, M.; Doweck, I.; Ilan, N.; Vlodavsky, I. Heparanase Enhances Tumor Growth and Chemoresistance by Promoting Autophagy. Cancer Res. 2015, 75, 3946-3957. [CrossRef]

111. Amin, R.; Tripathi, K.; Sanderson, R.D. Nuclear Heparanase Regulates Chromatin Remodeling, Gene Expression and PTEN Tumor Suppressor Function. Cells 2020, 9, 2038. [CrossRef]

112. Yang, Y.; Gorzelanny, C.; Bauer, A.T.; Halter, N.; Komljenovic, D.; Bäuerle, T.; Borsig, L.; Roblek, M.; Schneider, S.W. Nuclear heparanase-1 activity suppresses melanoma progression via its DNA-binding affinity. Oncogene 2015, 34, 5832-5842. [CrossRef]

113. Schubert, S.Y.; Ilan, N.; Shushy, M.; Ben-Izhak, O.; Vlodavsky, I.; Goldshmidt, O. Human heparanase nuclear localization and enzymatic activity. Lab. Investig. 2004, 84, 535-544. [CrossRef]

114. Sanderson, R.D.; Bandari, S.K.; Vlodavsky, I. Proteases and glycosidases on the surface of exosomes: Newly discovered mechanisms for extracellular remodeling. Matrix Biol. 2019, 75, 160-169. [CrossRef] [PubMed]

115. Thompson, C.A.; Purushothaman, A.; Ramani, V.C.; Vlodavsky, I.; Sanderson, R.D. Heparanase Regulates Secretion, Composition, and Function of Tumor Cell-derived Exosomes. J. Biol. Chem. 2013, 288, 10093-10099. [CrossRef] [PubMed]

116. Christianson, H.C.; Svensson, K.J.; van Kuppevelt, T.H.; Li, J.-P.; Belting, M. Cancer cell exosomes depend on cell-surface heparan sulfate proteoglycans for their internalization and functional activity. Proc. Natl. Acad. Sci. USA 2013, 110, 17380-17385. [CrossRef] [PubMed] 
117. Wei, J.; Hu, M.; Huang, K.; Lin, S.; Du, H. Roles of Proteoglycans and Glycosaminoglycans in Cancer Development and Progression. Int. J. Mol. Sci. 2020, 21, 5983. [CrossRef]

118. Brassart-Pasco, S.; Brézillon, S.; Brassart, B.; Ramont, L.; Oudart, J.-B.; Monboisse, J.C. Tumor Microenvironment: Extracellular Matrix Alterations Influence Tumor Progression. Front. Oncol. 2020, 10, 397. [CrossRef]

119. Toba-Ichihashi, Y.; Yamaoka, T.; Ohmori, T.; Ohba, M. Up-regulation of Syndecan-4 contributes to TGF- $\beta 1$-induced epithelial to mesenchymal transition in lung adenocarcinoma A549 cells. Biochem. Biophys. Rep. 2016, 5, 1-7. [CrossRef]

120. Matsuda, K.; Maruyama, H.; Guo, F.; Kleeff, J.; Itakura, J.; Matsumoto, Y.; Lander, A.D.; Korc, M. Glypican-1 is overexpressed in human breast cancer and modulates the mitogenic effects of multiple heparin-binding growth factors in breast cancer cells. Cancer Res. 2001, 61, 5562-5569.

121. Kovalszky, I.; Hjerpe, A.; Dobra, K. Nuclear translocation of heparan sulfate proteoglycans and their functional significance. Biochim. Biophys. Acta Gen. Subj. 2014, 1840, 2491-2497. [CrossRef]

122. Stewart, M.D.; Sanderson, R.D. Heparan sulfate in the nucleus and its control of cellular functions. Matrix Biol. 2014, 35, 56-59. [CrossRef]

123. Stewart, M.D.; Ramani, V.C.; Sanderson, R.D. Shed Syndecan-1 Translocates to the Nucleus of Cells Delivering Growth Factors and Inhibiting Histone Acetylation. J. Biol. Chem. 2015, 290, 941-949. [CrossRef]

124. Bergers, G.; Benjamin, L.E. Tumorigenesis and the angiogenic switch. Nat. Rev. Cancer 2003, 3, 401-410. [CrossRef] [PubMed]

125. Fuster, M.M.; Wang, L. Endothelial Heparan Sulfate in Angiogenesis. Prog. Mol. Biol. Transl. Sci. 2010, 93, 179-212. [CrossRef] [PubMed]

126. Corti, F.; Wang, Y.; Rhodes, J.M.; Atri, D.; Archer-Hartmann, S.; Zhang, J.; Zhuang, Z.W.; Chen, D.; Wang, T.; Wang, Z.; et al. $\mathrm{N}$-terminal syndecan-2 domain selectively enhances 6-O heparan sulfate chains sulfation and promotes VEGFA165-dependent neovascularization. Nat. Commun. 2019, 10, 1562. [CrossRef] [PubMed]

127. Iozzo, R.V.; Antonio, J.D.S. Heparan sulfate proteoglycans: Heavy hitters in the angiogenesis arena. J. Clin. Investig. 2001, 108, 349-355. [CrossRef]

128. Lamorte, S.; Ferrero, S.; Aschero, S.; Monitillo, L.; Bussolati, B.; Omede, P.; Ladetto, M.; Camussi, G. Syndecan-1 promotes the angiogenic phenotype of multiple myeloma endothelial cells. Leukemia 2011, 26, 1081-1090. [CrossRef]

129. Cohen, I.R.; Murdoch, A.D.; Naso, M.F.; Marchetti, D.; Berd, D.; Iozzo, R.V. Abnormal expression of perlecan proteoglycan in metastatic melanomas. Cancer Res. 1994, 54, 5771-5774.

130. Iozzo, R.V.; Sanderson, R.D. Proteoglycans in cancer biology, tumour microenvironment and angiogenesis. J. Cell. Mol. Med. 2011, 15, 1013-1031. [CrossRef]

131. Arokiasamy, S.; Balderstone, M.J.M.; de Rossi, G.; Whiteford, J.R. Syndecan-3 in Inflammation and Angiogenesis. Front. Immunol. 2020, 10, 3031. [CrossRef]

132. De Rossi, G.; Whiteford, J.R. A novel role for syndecan-3 in angiogenesis. F1000Research 2013, 2, 270. [CrossRef]

133. Lim, H.C.; Multhaupt, H.A.B.; Couchman, J.R. Cell surface heparan sulfate proteoglycans control adhesion and invasion of breast carcinoma cells. Mol. Cancer 2015, 14, 15-18. [CrossRef]

134. Sanderson, R.D. Heparan sulfate proteoglycans in invasion and metastasis. Semin. Cell Dev. Biol. 2001, 12, 89-98. [CrossRef] [PubMed]

135. Charni, F.; Friand, V.; Haddad, O.; Hlawaty, H.; Martin, L.; Vassy, R.; Oudar, O.; Gattegno, L.; Charnaux, N.; Sutton, A. Syndecan-1 and syndecan- 4 are involved in RANTES/CCL5-induced migration and invasion of human hepatoma cells. Biochim. Biophys. Acta Gen. Subj. 2009, 1790, 1314-1326. [CrossRef] [PubMed]

136. Reiland, J.; Sanderson, R.D.; Waguespack, M.; Barker, S.A.; Long, R.; Carson, D.D.; Marchetti, D. Heparanase Degrades Syndecan-1 and Perlecan Heparan Sulfate. J. Biol. Chem. 2004, 279, 8047-8055. [CrossRef] [PubMed]

137. Wang, S.; Zhang, X.; Wang, G.; Cao, B.; Yang, H.; Jin, L.; Cui, M.; Mao, Y. Syndecan-1 suppresses cell growth and migration via blocking JAK1/STAT3 and Ras/Raf/MEK/ERK pathways in human colorectal carcinoma cells. BMC Cancer 2019, 19, 1160. [CrossRef] [PubMed]

138. Liu, Z.; Jin, H.; Yang, S.; Cao, H.; Zhang, Z.; Wen, B.; Zhou, S. SDC1 knockdown induces epithelial-mesenchymal transition and invasion of gallbladder cancer cells via the ERK/Snail pathway. J. Int. Med. Res. 2020, 48, 19-32. [CrossRef] [PubMed]

139. Mikami, S.; Ohashi, K.; Usui, Y.; Nemoto, T.; Katsube, K.-I.; Yanagishita, M.; Nakajima, M.; Nakamura, K.; Koike, M. Loss of Syndecan-1 and Increased Expression of Heparanase in Invasive Esophageal Carcinomas. Jpn. J. Cancer Res. 2001, 92, 1062-1073. [CrossRef] [PubMed]

140. Lim, H.C.; Couchman, J.R. Syndecan-2 regulation of morphology in breast carcinoma cells is dependent on RhoGTPases. Biochim. Biophys. Acta BBA Gen. Subj. 2014, 1840, 2482-2490. [CrossRef]

141. Park, H.; Kim, Y.; Lim, Y.; Han, I.; Oh, E.-S. Syndecan-2 Mediates Adhesion and Proliferation of Colon Carcinoma Cells. J. Biol. Chem. 2002, 277, 29730-29736. [CrossRef]

142. De Oliveira, T.; Abiatari, I.; Raulefs, S.; Sauliunaite, D.; Reiser-Erkan, T.M.C.; Kong, B.; Friess, H.; Michalski, C.W.; Kleeff, J. Syndecan-2 promotes perineural invasion and cooperates with K-ras to induce an invasive pancreatic cancer cell phenotype. Mol. Cancer 2012, 11, 19. [CrossRef]

143. Mytilinaiou, M.; Nikitovic, D.; Berdiaki, A.; Kostouras, A.; Papoutsidakis, A.; Tsatsakis, A.M.; Tzanakakis, G.N. Emerging roles of syndecan 2 in epithelial and mesenchymal cancer progression. IUBMB Life 2017, 69, 824-833. [CrossRef] 
144. Aikawa, T.; Whipple, C.A.; Lopez, M.E.; Gunn, J.; Young, A.; Lander, A.D.; Korc, M. Glypican-1 modulates the angiogenic and metastatic potential of human and mouse cancer cells. J. Clin. Investig. 2008, 118, 89-99. [CrossRef] [PubMed]

145. Duan, L.; Hu, X.-Q.; Feng, D.-Y.; Lei, S.-Y.; Hu, G.-H. GPC-1 may serve as a predictor of perineural invasion and a prognosticator of survival in pancreatic cancer. Asian J. Surg. 2013, 36, 7-12. [CrossRef] [PubMed]

146. Hara, H.; Takahashi, T.; Serada, S.; Fujimoto, M.; Ohkawara, T.; Nakatsuka, R.; Harada, E.; Nishigaki, T.; Takahashi, Y.; Nojima, S.; et al. Overexpression of glypican-1 implicates poor prognosis and their chemoresistance in oesophageal squamous cell carcinoma. Br. J. Cancer 2016, 115, 66-75. [CrossRef]

147. Su, G.; Meyer, K.; Nandini, C.D.; Qiao, D.; Salamat, S.; Friedl, A. Glypican-1 Is Frequently Overexpressed in Human Gliomas and Enhances FGF-2 Signaling in Glioma Cells. Am. J. Pathol. 2006, 168, 2014-2026. [CrossRef] [PubMed]

148. Saito, T.; Sugiyama, K.; Hama, S.; Yamasaki, F.; Takayasu, T.; Nosaka, R.; Onishi, S.; Muragaki, Y.; Kawamata, T.; Kurisu, K. High Expression of Glypican-1 Predicts Dissemination and Poor Prognosis in Glioblastomas. World Neurosurg. 2017, 105, 282-288. [CrossRef]

149. Montalbano, M.; Rastellini, C.; McGuire, J.T.; Prajapati, J.; Shirafkan, A.; Vento, R.; Cicalese, L. Role of Glypican-3 in the growth, migration and invasion of primary hepatocytes isolated from patients with hepatocellular carcinoma. Cell. Oncol. 2017, 41, 169-184. [CrossRef]

150. Zhou, F.; Shang, W.; Yu, X.; Tian, J. Glypican-3: A promising biomarker for hepatocellular carcinoma diagnosis and treatment. Med. Res. Rev. 2018, 38, 741-767. [CrossRef]

151. Yiu, G.K.; Kaunisto, A.; Chin, Y.R.; Toker, A. NFAT promotes carcinoma invasive migration through glypican-6. Biochem. J. 2011, 440, 157-166. [CrossRef]

152. Nishida, N.; Yano, H.; Nishida, T.; Kamura, T.; Kojiro, M. Angiogenesis in cancer. Vasc. Heal. Risk Manag. 2006, 2, $213-219$. [CrossRef]

153. Elgundi, Z.; Papanicolaou, M.; Major, G.; Cox, T.R.; Melrose, J.; Whitelock, J.M.; Farrugia, B.L. Cancer Metastasis: The Role of the Extracellular Matrix and the Heparan Sulfate Proteoglycan Perlecan. Front. Oncol. 2020, 9, 1482. [CrossRef]

154. Matsumoto, A.; Ono, M.; Fujimoto, Y.; Gallo, R.L.; Bernfield, M.; Kohgo, Y. Reduced expression of syndecan-1 in human hepatocellular carcinoma with high metastatic potential. Int. J. Cancer 1997, 74, 482-491. [CrossRef]

155. Fujiya, M.; Watari, J.; Ashida, T.; Honda, M.; Tanabe, H.; Fujiki, T.; Saitoh, Y.; Kohgo, Y. Reduced Expression of Syndecan-1 Affects Metastatic Potential and Clinical Outcome in Patients with Colorectal Cancer. Jpn. J. Cancer Res. 2001, 92, 1074-1081. [CrossRef] [PubMed]

156. Saleh, M.E.; Gadalla, R.; Hassan, H.; Afifi, A.; Götte, M.; El-Shinawi, M.; Mohamed, M.M.; Ibrahim, S.A. The immunomodulatory role of tumor Syndecan-1 (CD138) on ex vivo tumor microenvironmental CD4+ T cell polarization in inflammatory and noninflammatory breast cancer patients. PLoS ONE 2019, 14, e0217550. [CrossRef] [PubMed]

157. Ibrahim, S.A.; Gadalla, R.; El-Ghonaimy, E.A.; Samir, O.; Mohamed, H.T.; Hassan, H.; Greve, B.; El-Shinawi, M.; Mohamed, M.M.; Gotte, M. Syndecan-1 is a novel molecular marker for triple negative inflammatory breast cancer and modulates the cancer stem cell phenotype via the IL-6/STAT3, Notch and EGFR signaling pathways. Mol. Cancer 2017, 16, 1-19. [CrossRef] [PubMed]

158. Fares, Y.; Fares, M.Y.; Khachfe, H.H.; Salhab, H.A.; Fares, Y. Molecular principles of metastasis: A hallmark of cancer revisited. Signal. Transduct. Target. Ther. 2020, 5, 1-17. [CrossRef]

159. Oliveira-Ferrer, L.; Legler, K.; Milde-Langosch, K. Role of protein glycosylation in cancer metastasis. Semin. Cancer Biol. 2017, 44, 141-152. [CrossRef]

160. Cerezo-Magaña, M.; Bång-Rudenstam, A.; Belting, M. The pleiotropic role of proteoglycans in extracellular vesicle mediated communication in the tumor microenvironment. Semin. Cancer Biol. 2020, 62, 99-107. [CrossRef]

161. Tkach, M.; Théry, C. Communication by Extracellular Vesicles: Where We Are and Where We Need to Go. Cell 2016, 164, 1226-1232. [CrossRef]

162. Colombo, M.; Raposo, G.; Théry, C. Biogenesis, secretion, and intercellular interactions of exosomes and other extracellular vesicles. Annu. Rev. Cell Dev. Biol. 2014, 30, 255-289. [CrossRef]

163. Cocozza, F.; Grisard, E.; Martin-Jaular, L.; Mathieu, M.; Théry, C. SnapShot: Extracellular Vesicles. Cell 2020, $182,262-262 . e 1$. [CrossRef]

164. Hoshino, A.; Costa-Silva, B.; Shen, T.-L.; Rodrigues, G.; Hashimoto, A.; Mark, M.T.; Molina, H.; Kohsaka, S.; Di Giannatale, A.; Ceder, S.; et al. Tumour exosome integrins determine organotropic metastasis. Nature 2015, 527, 329-335. [CrossRef] [PubMed]

165. Adem, B.; Vieira, P.F.; Melo, S.A. Decoding the Biology of Exosomes in Metastasis. Trends Cancer 2020, 6, 20-30. [CrossRef] [PubMed]

166. Kalluri, R.; le Bleu, V.S. The biology, function, and biomedical applications of exosomes. Science 2020, 367, eaau6977. [CrossRef] [PubMed]

167. Lane, R.E.; Korbie, D.; Hill, M.M.; Trau, M. Extracellular vesicles as circulating cancer biomarkers: Opportunities and challenges. Clin. Transl. Med. 2018, 7, 14. [CrossRef] [PubMed]

168. Pang, B.; Zhu, Y.; Ni, J.; Thompson, J.; Malouf, D.; Bucci, J.; Graham, P.; Li, Y. Extracellular vesicles: The next generation of biomarkers for liquid biopsy-based prostate cancer diagnosis. Theranostics 2020, 10, 2309-2326. [CrossRef]

169. Friand, V.; David, G.; Zimmermann, P. Syntenin and syndecan in the biogenesis of exosomes. Biol. Cell 2015, 107, 331-341. [CrossRef] 
170. Imjeti, N.S.; Menck, K.; Egea-Jimenez, A.L.; Lecointre, C.; Lembo, F.; Bouguenina, H.; Badache, A.; Ghossoub, R.; David, G.; Roche, S.; et al. Syntenin mediates SRC function in exosomal cell-to-cell communication. Proc. Natl. Acad. Sci. USA 2017, 114, 12495-12500. [CrossRef]

171. Baietti, M.F.; Zhang, Z.; Mortier, E.; Melchior, A.; DeGeest, G.; Geeraerts, A.; Ivarsson, Y.; Depoortere, F.; Coomans, C.; Vermeiren, E.; et al. Syndecan-syntenin-ALIX regulates the biogenesis of exosomes. Nat. Cell Biol. 2012, 14, 677-685. [CrossRef]

172. Hurley, J.H.; Odorizzi, G. Get on the exosome bus with ALIX. Nat. Cell Biol. 2012, 14, 654-655. [CrossRef]

173. Ghossoub, R.; Lembo, F.; Rubio, A.; Gaillard, C.B.; Bouchet, J.; Vitale, N.; Slavík, J.; Machala, M.; Zimmermann, P. Syntenin-ALIX exosome biogenesis and budding into multivesicular bodies are controlled by ARF6 and PLD2. Nat. Commun. 2014, 5, 3477. [CrossRef]

174. David, G.; Zimmermann, P. Heparanase Involvement in Exosome Formation. Adv. Exp. Med. Biol. 2020, 1221, 285-307. [CrossRef] [PubMed]

175. Sanderson, R.D.; Elkin, M.; Rapraeger, A.C.; Ilan, N.; Vlodavsky, I. Heparanase regulation of cancer, autophagy and inflammation: New mechanisms and targets for therapy. FEBS J. 2017, 284, 42-55. [CrossRef] [PubMed]

176. Roucourt, B.; Meeussen, S.; Bao, J.; Zimmermann, P.; David, G. Heparanase activates the syndecan-syntenin-ALIX exosome pathway. Cell Res. 2015, 25, 412-428. [CrossRef] [PubMed]

177. Cerezo-Magana, M.; Christianson, H.C.; van Kuppevelt, T.H.; Forsberg-Nilsson, K.; Belting, M. Hypoxic induction of exosome uptake through proteoglycan dependent endocytosis fuels the lipid droplet phenotype in glioma. Mol. Cancer Res. 2020, 10, 1158-1541. [CrossRef]

178. Buzás, E.I.; Tóth, E.Á.; Sódar, B.W.; Szabó-Taylor, K.É. Molecular interactions at the surface of extracellular vesicles. Semin. Immunopathol. 2018, 40, 453-464. [CrossRef]

179. Purushothaman, A.; Bandari, S.K.; Liu, J.; Mobley, J.A.; Brown, E.E.; Sanderson, R.D. Fibronectin on the Surface of Myeloma Cell-derived Exosomes Mediates Exosome-Cell Interactions. J. Biol. Chem. 2016, 291, 1652-1663. [CrossRef]

180. Nangami, G.; Koumangoye, R.; Goodwin, J.S.; Sakwe, A.M.; Marshall, D.; Higginbotham, J.; Ochieng, J. Fetuin-A associates with histones intracellularly and shuttles them to exosomes to promote focal adhesion assembly resulting in rapid adhesion and spreading in breast carcinoma cells. Exp. Cell Res. 2014, 328, 388-400. [CrossRef]

181. Berenguer, J.; Lagerweij, T.; Zhao, X.W.; Dusoswa, S.; van der Stoop, P.; Westerman, B.; de Gooijer, M.C.; Zoetemelk, M.; Zomer, A.; Crommentuijn, M.H.W.; et al. Glycosylated extracellular vesicles released by glioblastoma cells are decorated by CCL18 allowing for cellular uptake via chemokine receptor CCR8. J. Extracell. Vesicles 2018, 7, 1446660. [CrossRef]

182. Arruebo, M.; Vilaboa, N.; Saez, B.; Lambea, J.; Tres, A.; Valladares, M.; González-Fernández, Á. Assessment of the Evolution of Cancer Treatment Therapies. Cancers 2011, 3, 3279-3330. [CrossRef]

183. Wichert, A.; Stege, A.; Midorikawa, Y.; Holm, P.S.; Lage, H. Glypican-3 is involved in cellular protection against mitoxantrone in gastric carcinoma cells. Oncogene 2003, 23, 945-955. [CrossRef]

184. Mahtouk, K.; Hose, D.; Raynaud, P.; Hundemer, M.; Jourdan, M.; Jourdan, E.; Pantesco, V.; Baudard, M.; de Vos, J.; Larroque, M.; et al. Heparanase influences expression and shedding of syndecan-1, and its expression by the bone marrow environment is a bad prognostic factor in multiple myeloma. Blood 2007, 109, 4914-4923. [CrossRef] [PubMed]

185. Ramani, V.C.; Purushothaman, A.; Stewart, M.D.; Thompson, C.A.; Vlodavsky, I.; Au, J.L.-S.; Sanderson, R.D. The heparanase/syndecan-1 axis in cancer: Mechanisms and therapies. FEBS J. 2013, 280, 2294-2306. [CrossRef]

186. Barbareschi, M.; Aldovini, D.; Cangi, M.G.; Pecciarini, L.; Veronese, S.; Caffo, O.; Lucenti, A.; Palma, P.D. High syndecan-1 expression in breast carcinoma is related to an aggressive phenotype and to poorer prognosis. Cancer 2003, 98, 474-483. [CrossRef] [PubMed]

187. Nguyen, T.L.; Grizzle, W.E.; Zhang, K.; Hameed, O.; Siegal, G.P.; Wei, S. Syndecan-1 Overexpression Is Associated with Nonluminal Subtypes and Poor Prognosis in Advanced Breast Cancer. Am. J. Clin. Pathol. 2013, 140, 468-474. [CrossRef]

188. Ramani, V.C.; Zhan, F.; He, J.; Barbieri, P.; Noseda, A.; Tricot, G.; Sanderson, R.D. Targeting heparanase overcomes chemoresistance and diminishes relapse in myeloma. Oncotarget 2015, 7, 1598-1607. [CrossRef] [PubMed]

189. Götte, M.; Kersting, C.; Ruggiero, M.; Tio, J.; Tulusan, A.H.; Kiesel, L.; Wülfing, P. Predictive value of syndecan-1 expression for the response to neoadjuvant chemotherapy of primary breast cancer. Anticanc. Res. 2006, 26, 621-627.

190. Suarez, E.R.; Paredes-Gamero, E.J.; del Giglio, A.; Tersariol, I.L.S.; Nader, H.B.; Pinhal, M.A.S. Heparan sulfate mediates trastuzumab effect in breast cancer cells. BMC Cancer 2013, 13, 444. [CrossRef]

191. Meirovitz, A.; Hermano, E.; Lerner, I.; Zcharia, E.; Pisano, C.; Peretz, T.; Elkin, M. Role of Heparanase in Radiation-Enhanced Invasiveness of Pancreatic Carcinoma. Cancer Res. 2011, 71, 2772-2780. [CrossRef]

192. Li, J.; Meng, X.; Hu, J.; Zhang, Y.; Dang, Y.; Wei, L.; Shi, M. Heparanase promotes radiation resistance of cervical cancer by upregulating hypoxia inducible factor 1. Am. J. Cancer Res. 2017, 7, 234-244.

193. Wang, X.; Zuo, D.; Chen, Y.; Li, W.; Liu, R.; He, Y.; Ren, L.; Zhou, L.; Deng, T.; Ying, G.; et al. Shed Syndecan-1 is involved in chemotherapy resistance via the EGFR pathway in colorectal cancer. Br. J. Cancer 2014, 111, 1965-1976. [CrossRef]

194. Ramani, V.C.; Sanderson, R.D. Chemotherapy stimulates syndecan-1 shedding: A potentially negative effect of treatment that may promote tumor relapse. Matrix Biol. 2014, 35, 215-222. [CrossRef] [PubMed]

195. Keklikoglou, I.; Cianciaruso, C.; Güç, E.; Squadrito, M.L.; Spring, L.M.; Tazzyman, S.; Lambein, L.; Poissonnier, A.; Ferraro, G.B.; Baer, C.; et al. Chemotherapy elicits pro-metastatic extracellular vesicles in breast cancer models. Nat. Cell Biol. 2019, 21, 190-202. [CrossRef] [PubMed] 
196. Viola, M.; Brüggemann, K.; Karousou, E.; Caon, I.; Caravà, E.; Vigetti, D.; Greve, B.; Stock, C.; de Luca, G.; Passi, A.; et al. MDA-MB-231 breast cancer cell viability, motility and matrix adhesion are regulated by a complex interplay of heparan sulfate, chondroitin-/dermatan sulfate and hyaluronan biosynthesis. Glycoconj. J. 2016, 34, 411-420. [CrossRef] [PubMed]

197. Alizadeh, A.A.; Aranda, V.V.; Bardelli, A.A.; Blanpain, C.; Bock, C.C.; Borowski, C.C.; Caldas, C.; Califano, A.A.; Doherty, M.M.; Elsner, M.M.; et al. Toward understanding and exploiting tumor heterogeneity. Nat. Med. 2015, 21, 846-853. [CrossRef] [PubMed]

198. Marusyk, A.; Almendro, V.; Polyak, K. Intra-tumour heterogeneity: A looking glass for cancer? Nat. Rev. Cancer 2012, 12, 323-334. [CrossRef]

199. Zardavas, D.; Irrthum, A.A.; Swanton, C.; Piccart-Gebhart, M. Clinical management of breast cancer heterogeneity. Nat. Rev. Clin. Oncol. 2015, 12, 381-394. [CrossRef]

200. Belting, M. Glycosaminoglycans in cancer treatment. Thromb. Res. 2014, 133, S95-S101. [CrossRef]

201. Espinoza-Sánchez, N.A.; Gotte, M. Role of cell surface proteoglycans in cancer immunotherapy. Semin. Cancer Biol. 2020, 62, 48-67. [CrossRef]

202. Ripsman, D.; Fergusson, D.; Montroy, J.; Auer, R.C.; Huang, J.W.; Dobriyal, A.; Wesch, N.; Carrier, M.; Lalu, M.M. A systematic review on the efficacy and safety of low molecular weight heparin as an anticancer therapeutic in preclinical animal models. Thromb. Res. 2020, 195, 103-113. [CrossRef]

203. Ramani, V.C.; Vlodavsky, I.; Ng, M.; Zhang, Y.; Barbieri, P.; Noseda, A.; Sanderson, R.D. Chemotherapy induces expression and release of heparanase leading to changes associated with an aggressive tumor phenotype. Matrix Biol. 2016, 55, 22-34. [CrossRef]

204. Bandari, S.K.; Purushothaman, A.; Ramani, V.C.; Brinkley, G.J.; Chandrashekar, D.S.; Varambally, S.; Mobley, J.A.; Zhang, Y.; Brown, E.E.; Vlodavsky, I.; et al. Chemotherapy induces secretion of exosomes loaded with heparanase that degrades extracellular matrix and impacts tumor and host cell behavior. Matrix Biol. 2018, 65, 104-118. [CrossRef] [PubMed]

205. Morla, S. Glycosaminoglycans and Glycosaminoglycan Mimetics in Cancer and Inflammation. Int. J. Mol. Sci. 2019, 20, 1963. [CrossRef] [PubMed]

206. Moussa, L.; Demarquay, C.; Réthoré, G.; Benadjaoud, M.A.; Siñeriz, F.; Pattappa, G.; Guicheux, J.; Weiss, P.; Barritault, D.; Mathieu, N. Heparan Sulfate Mimetics: A New Way to Optimize Therapeutic Effects of Hydrogel-Embedded Mesenchymal Stromal Cells in Colonic Radiation-Induced Damage. Sci. Rep. 2019, 9, 164. [CrossRef] [PubMed]

207. Veraldi, N.; Zouggari, N.; de Agostini, A. The Challenge of Modulating Heparan Sulfate Turnover by Multitarget Heparin Derivatives. Molecules 2020, 25, 390. [CrossRef] [PubMed]

208. Wang, W.; Gopal, S.; Pocock, R.; Xiao, Z.-C. Glycan Mimetics from Natural Products: New Therapeutic Opportunities for Neurodegenerative Disease. Molecules 2019, 24, 4604. [CrossRef]

209. Whiteside, T.L. The potential of tumor-derived exosomes for noninvasive cancer monitoring. Expert Rev. Mol. Diagn. 2015, 15, 1293-1310. [CrossRef]

210. Buscail, E.; Alix-Panabières, C.; Quincy, P.; Cauvin, T.; Chauvet, A.; Degrandi, O.; Caumont, C.; Verdon, S.; Lamrissi, I.; Moranvillier, I.; et al. High Clinical Value of Liquid Biopsy to Detect Circulating Tumor Cells and Tumor Exosomes in Pancreatic Ductal Adenocarcinoma Patients Eligible for Up-Front Surgery. Cancers 2019, 11, 1656. [CrossRef]

211. Zhao, Z.; Fan, J.; Hsu, Y.-M.S.; Lyon, C.J.; Ning, B.; Hu, T.Y. Extracellular vesicles as cancer liquid biopsies: From discovery, validation, to clinical application. Lab. Chip 2019, 19, 1114-1140. [CrossRef]

212. Dredge, K.; Brennan, T.V.; Hammond, E.; Lickliter, J.D.; Lin, L.; Bampton, D.; Handley, P.; Lankesheer, F.; Morrish, G.; Yang, Y.; et al. A Phase I study of the novel immunomodulatory agent PG545 (pixatimod) in subjects with advanced solid tumours. Br. J. Cancer 2018, 118, 1035-1041. [CrossRef]

213. Hammond, E.; Haynes, N.M.; Cullinane, C.; Brennan, T.V.; Bampton, D.; Handley, P.; Karoli, T.; Lanksheer, F.; Lin, L.; Yang, Y.; et al. Immunomodulatory activities of pixatimod: Emerging nonclinical and clinical data, and its potential utility in combination with PD-1 inhibitors. J. Immunother. Cancer 2018, 6, 54. [CrossRef]

214. Weissmann, M.; Bhattacharya, U.; Feld, S.; Hammond, E.; Ilan, N.; Vlodavsky, I. The heparanase inhibitor PG545 is a potent anti-lymphoma drug: Mode of action. Matrix Biol. 2019, 77, 58-72. [CrossRef] [PubMed]

215. Mayfosh, A.J.; Baschuk, N.; Hulett, M.D. Leukocyte Heparanase: A Double-Edged Sword in Tumor Progression. Front. Oncol. 2019, 9, 331. [CrossRef] [PubMed]

216. Jayatilleke, K.M.; Hulett, M.D. Heparanase and the hallmarks of cancer. J. Transl. Med. 2020, 18, 1-25. [CrossRef] [PubMed]

217. Piperigkou, Z.; Mohr, B.; Karamanos, N.; Gotte, M. Shed proteoglycans in tumor stroma. Cell Tissue Res. 2016, 365, 643-655. [CrossRef] [PubMed]

218. Mohan, C.D.; Hari, S.; Preetham, H.D.; Rangappa, S.; Barash, U.; Ilan, N.; Nayak, S.C.; Gupta, V.K.; Vlodavsky, I. Targeting Heparanase in Cancer: Inhibition by Synthetic, Chemically Modified, and Natural Compounds. iScience 2019, 15, 360-390. [CrossRef]

219. Kisker, O.; Becker, C.M.; Prox, D.; Fannon, M.; D’Amato, R.; Flynn, E.; E Fogler, W.; Sim, B.K.; Allred, E.N.; Pirie-Shepherd, S.R.; et al. Continuous administration of endostatin by intraperitoneally implanted osmotic pump improves the efficacy and potency of therapy in a mouse xenograft tumor model. Cancer Res. 2001, 61, 7669-7674.

220. Walia, A.; Yang, J.F.; Huang, Y.-H.; Rosenblatt, M.I.; Chang, J.-H.; Azar, D.T. Endostatin's emerging roles in angiogenesis, lymphangiogenesis, disease, and clinical applications. Biochim. Biophys. Acta Gen. Subj. 2015, 1850, 2422-2438. [CrossRef] 
221. Sato, K.; Akiyama, H.; Kogure, Y.; Suwa, Y.; Momiyama, M.; Ishibe, A.; Endo, I. [A Case of Rhabdomyolysis Related to SOX Therapy for Liver Metastasis of Gastric Cancer]. Gan Kagaku Ryoho. Cancer Chemother. 2017, 44, 329-331.

222. Wang, M.; Yang, H.; Sui, Y.; Guo, X.; Tan, X.; Li, Y. Endostar continuous intravenous infusion combined with S-1 and oxaliplatin chemotherapy could be effective in treating liver metastasis from gastric cancer. J. Cancer Res. Ther. 2018, 14, 1148. [CrossRef]

223. Xiao, C.; Qian, J.; Zheng, Y.; Song, F.; Wang, Q.; Jiang, H.; Mao, C.; Xu, N. A phase II study of biweekly oxaliplatin plus S-1 combination chemotherapy as a first-line treatment for patients with metastatic or advanced gastric cancer in China. Medicine 2019, 98, e15696. [CrossRef]

224. Cheng, Y.-J.; Meng, C.-T.; Ying, H.-Y.; Zhou, J.-F.; Yan, X.-Y.; Gao, X.; Zhou, N.; Bai, C.-M. Effect of Endostar combined with chemotherapy in advanced well-differentiated pancreatic neuroendocrine tumors. Medicine 2018, 97, e12750. [CrossRef] [PubMed]

225. Billings, P.C.; Pacifici, M. Interactions of signaling proteins, growth factors and other proteins with heparan sulfate: Mechanisms and mysteries. Connect. Tissue Res. 2015, 56, 272-280. [CrossRef] [PubMed]

226. Wang, H.; Liu, Z.; An, C.; Li, H.; Hu, F.; Dong, S. Self-Assembling Glycopeptide Conjugate as a Versatile Platform for Mimicking Complex Polysaccharides. Adv. Sci. 2020, 7, 2001264. [CrossRef] [PubMed]

227. Reily, C.; Stewart, T.J.; Renfrow, M.B.; Novak, J. Glycosylation in health and disease. Nat. Rev. Nephrol. 2019, 15, 346-366. [CrossRef] [PubMed]

228. Coombe, D.R.; Gandhi, N.S. Heparanase: A Challenging Cancer Drug Target. Front. Oncol. 2019, 9, 1316. [CrossRef] [PubMed]

229. Denys, A.; Allain, F. The Emerging Roles of Heparan Sulfate 3-O-Sulfotransferases in Cancer. Front. Oncol. 2019, 9, 507. [CrossRef]

230. Hellec, C.; Delos, M.; Carpentier, M.; Denys, A.; Allain, F. The heparan sulfate 3-O-sulfotransferases (HS3ST) 2, 3B and 4 enhance proliferation and survival in breast cancer MDA-MB-231 cells. PLoS ONE 2018, 13, e0194676. [CrossRef]

231. Jagannath, S.; Heffner, L.T.; Ailawadhi, S.; Munshi, N.C.; Zimmerman, T.M.; Rosenblatt, J.; Lonial, S.; Chanan-Khan, A.; Ruehle, M.; Rharbaoui, F.; et al. Indatuximab Ravtansine (BT062) Monotherapy in Patients with Relapsed and/or Refractory Multiple Myeloma. Clin. Lymphoma Myeloma Leuk. 2019, 19, 372-380. [CrossRef]

232. Guo, B.; Chen, M.; Han, Q.; Hui, F.; Dai, H.; Zhang, W.; Zhang, Y.; Wang, Y.; Zhu, H.; Han, W. CD138-directed adoptive immunotherapy of chimeric antigen receptor (CAR)-modified T cells for multiple myeloma. J. Cell. Immunother. 2016, 2, 28-35. [CrossRef]

233. Shimizu, Y.; Suzuki, T.; Yoshikawa, T.; Endo, I.; Nakatsura, T. Next-Generation Cancer Immunotherapy Targeting Glypican-3. Front. Oncol. 2019, 9, 248. [CrossRef]

234. Liu, X.; Gao, F.; Jiang, L.; Jia, M.; Ao, L.; Lu, M.; Gou, L.; Ho, M.; Jia, S.; Chen, F.; et al. 32A9, a novel human antibody for designing an immunotoxin and CAR-T cells against glypican-3 in hepatocellular carcinoma. J. Transl. Med. 2020, 18, 1-12. [CrossRef] [PubMed]

235. Li, N.; Gao, W.; Zhang, Y.-F.; Ho, M. Glypicans as Cancer Therapeutic Targets. Trends Cancer 2018, 4, 741-754. [CrossRef] [PubMed]

236. Casu, B.; Naggi, A.; Torri, G. Re-visiting the structure of heparin. Carbohydr. Res. 2015, 403, 60-68. [CrossRef] [PubMed]

237. Kakkar, A.K.; Levine, M.N.; Kadziola, Z.; Lemoine, N.R.; Low, V.; Patel, H.K.; Rustin, G.; Thomas, M.D.; Quigley, M.; Williamson, R.C. Low Molecular Weight Heparin, Therapy with Dalteparin, and Survival in Advanced Cancer: The Fragmin Advanced Malignancy Outcome Study (FAMOUS). J. Clin. Oncol. 2004, 22, 1944-1948. [CrossRef]

238. Ludwig, R.J. Therapeutic use of heparin beyond anticoagulation. Curr. Drug Discov. Technol. 2009, 6, 281-289. [CrossRef]

239. Pomin, V.H.; Mulloy, B. Current structural biology of the heparin interactome. Curr. Opin. Struct. Biol. 2015, 34, 17-25. [CrossRef]

240. Gong, F.; Jemth, P.; Galvis, M.L.E.; Vlodavsky, I.; Horner, A.; Lindahl, U.; Li, J.-P. Processing of Macromolecular Heparin by Heparanase. J. Biol. Chem. 2003, 278, 35152-35158. [CrossRef]

241. Naggi, A.; Casu, B.; Perez, M.; Torri, G.; Cassinelli, G.; Penco, S.; Pisano, C.; Giannini, G.; Ishai-Michaeli, R.; Vlodavsky, I. Modulation of the Heparanase-inhibiting Activity of Heparin through Selective Desulfation, GradedN-Acetylation, and Glycol Splitting. J. Biol. Chem. 2005, 280, 12103-12113. [CrossRef]

242. Ritchie, J.P.; Ramani, V.C.; Ren, Y.; Naggi, A.; Torri, G.; Casu, B.; Penco, S.; Pisano, C.; Carminati, P.; Tortoreto, M.; et al. SST0001, a Chemically Modified Heparin, Inhibits Myeloma Growth and Angiogenesis via Disruption of the Heparanase/Syndecan-1 Axis. Clin. Cancer Res. 2011, 17, 1382-1393. [CrossRef]

243. Karoli, T.; Liu, L.; Fairweather, J.K.; Hammond, E.; Li, C.P.; Cochran, S.; Bergefall, K.; Trybala, E.; Addison, R.S.; Ferro, V. Synthesis, Biological Activity, and Preliminary Pharmacokinetic Evaluation of Analogues of a Phosphosulfomannan Angiogenesis Inhibitor (PI-88). J. Med. Chem. 2005, 48, 8229-8236. [CrossRef]

244. Khachigian, L.M.; Parish, C.R. Phosphomannopentaose sulfate (PI-88): Heparan sulfate mimetic with clinical potential in multiple vascular pathologies. Cardiovasc. Drug Rev. 2006, 22, 1-6. [CrossRef] [PubMed]

245. Kovacsovics, T.J.; Mims, A.; Salama, M.E.; Pantin, J.; Rao, N.; Kosak, K.M.; Ahorukomeye, P.; Glenn, M.J.; Deininger, M.W.N.; Boucher, K.M.; et al. Combination of the low anticoagulant heparin CX-01 with chemotherapy for the treatment of acute myeloid leukemia. Blood Adv. 2018, 2, 381-389. [CrossRef] [PubMed]

246. Pala, D.; Rivara, S.; Mor, M.; Milazzo, F.M.; Roscilli, G.; Pavoni, E.; Giannini, G. Kinetic analysis and molecular modeling of the inhibition mechanism of roneparstat (SST0001) on human heparanase. Glycobiology 2016, 26, 640-654. [CrossRef] [PubMed]

247. Dredge, K.; Hammond, E.; Davis, K.; Li, C.P.; Liu, L.; Johnstone, K.; Handley, P.; Wimmer, N.; Gonda, T.J.; Gautam, A.; et al. The PG500 series: Novel heparan sulfate mimetics as potent angiogenesis and heparanase inhibitors for cancer therapy. Investig. New Drugs 2009, 28, 276-283. [CrossRef] [PubMed] 
248. Ferro, V.; Dredge, K.; Liu, L.; Hammond, E.; Bytheway, I.; Li, C.; Johnstone, K.; Karoli, T.; Davis, K.; Copeman, E.; et al. PI-88 and Novel Heparan Sulfate Mimetics Inhibit Angiogenesis. Semin. Thromb. Hemost. 2007, 33, 557-568. [CrossRef]

249. Liu, C.-J.; Lee, P.-H.; Lin, D.-Y.; Wu, C.-C.; Jeng, L.-B.; Lin, P.-W.; Mok, K.-T.; Lee, W.-C.; Yeh, H.-Z.; Ho, M.-C.; et al. Heparanase inhibitor PI-88 as adjuvant therapy for hepatocellular carcinoma after curative resection: A randomized phase II trial for safety and optimal dosage. J. Hepatol. 2009, 50, 958-968. [CrossRef]

250. Liao, B.-Y.; Wang, Z.; Hu, J.; Liu, W.-F.; Shen, Z.-Z.; Zhang, X.; Yu, L.; Fan, J.; Zhou, J. PI-88 inhibits postoperative recurrence of hepatocellular carcinoma via disrupting the surge of heparanase after liver resection. Tumor Biol. 2015, 37, 2987-2998. [CrossRef]

251. Lewis, K.; Robinson, W.A.; Millward, M.J.; Powell, A.; Price, T.; Thomson, D.B.; Walpole, E.; Haydon, A.M.; Creese, B.R.; Roberts, K.L.; et al. A phase II study of the heparanase inhibitor PI-88 in patients with advanced melanoma. Investig. New Drugs 2007, 26, 89-94. [CrossRef]

252. Joglekar, M.V.; Diez, P.M.Q.; Marcus, S.; Qi, R.; Espinasse, B.; Wiesner, M.R.; Pempe, E.; Liu, J.; Monroe, D.M.; Arepally, G.M. Disruption of PF4/H multimolecular complex formation with a minimally anticoagulant heparin (ODSH). Thromb. Haemost. 2012, 107, 717-725. [CrossRef]

253. Winer, E.S.; Stone, R.M. Novel therapy in Acute myeloid leukemia (AML): Moving toward targeted approaches. Ther. Adv. Hematol. 2019, 10, 2040620719860645. [CrossRef]

254. Galli, M.; Chatterjee, M.; Grasso, M.; Specchia, G.; Magen, H.; Einsele, H.; Celeghini, I.; Barbieri, P.; Paoletti, D.; Pace, S.; et al. Phase I study of the heparanase inhibitor roneparstat: An innovative approach for ultiple myeloma therapy. Haematology 2018, 103, e469-e472. [CrossRef] [PubMed]

255. Ferro, V.; Liu, L.; Johnstone, K.D.; Wimmer, N.; Karoli, T.; Handley, P.; Rowley, J.; Dredge, K.; Li, C.P.; Hammond, E.; et al. Discovery of PG545: A Highly Potent and Simultaneous Inhibitor of Angiogenesis, Tumor Growth, and Metastasis. J. Med. Chem. 2012, 55, 3804-3813. [CrossRef] [PubMed]

256. Brennan, T.V.; Lin, L.; Brandstadter, J.D.; Rendell, V.R.; Dredge, K.; Huang, X.; Yang, Y. Heparan sulfate mimetic PG545-mediated antilymphoma effects require TLR9-dependent NK cell activation. J. Clin. Investig. 2015, 126, 207-219. [CrossRef] [PubMed]

257. Scott, E.; Guimond, C.J.M.-W.; Neha, S.; Gandhi-Julia, A.; Tree, K.R.; Buttigieg, N.C.; Elmore, M.J.; Joanna-Said, K.N.; Yin, X.S.; Alberto, A.; et al. Turnbull. Synthetic Heparan Sulfate Mimetic Pixatimod (PG545) Potently Inhibits SARS-CoV-2 By Disrupting the Spike-ACE2 interaction. bioRxiv 2020.

258. Cagno, V.; Tseligka, E.D.; Jones, S.T.; Tapparel, C. Heparan Sulfate Proteoglycans and Viral Attachment: True Receptors or Adaptation Bias? Viruses 2019, 11, 596. [CrossRef]

259. El Ghazal, R.; Yin, X.; Johns, S.C.; Swanson, L.; Macal, M.; Ghosh, P.; Zuniga, E.I.; Fuster, M.M. Glycan Sulfation Modulates Dendritic Cell Biology and Tumor Growth. Neoplasia 2016, 18, 294-306. [CrossRef]

260. Gatto, F.; Volpi, N.; Nilsson, H.; Nookaew, I.; Maruzzo, M.; Roma, A.; Johansson, M.E.; Stierner, U.; Lundstam, S.; Basso, U.; et al. Glycosaminoglycan Profiling in Patients' Plasma and Urine Predicts the Occurrence of Metastatic Clear Cell Renal Cell Carcinoma. Cell Rep. 2016, 15, 1822-1836. [CrossRef]

261. Brézillon, S.; Untereiner, V.; Mohamed, H.T.; Hodin, J.; Chatron-Colliet, A.; Maquart, F.-X.; Brézillon, S. Probing glycosaminoglycan spectral signatures in live cells and their conditioned media by Raman microspectroscopy. Analyst 2017, 142, 1333-1341. [CrossRef]

262. Li, N.; Spetz, M.R.; Ho, M. The Role of Glypicans in Cancer Progression and Therapy. J. Histochem. Cytochem. 2020, 68, 841-862. [CrossRef]

263. Lu, H.; Niu, F.; Liu, F.; Gao, J.; Sun, Y.; Zhao, X. Elevated glypican-1 expression is associated with an unfavorable prognosis in pancreatic ductal adenocarcinoma. Cancer Med. 2017, 6, 1181-1191. [CrossRef]

264. Zhou, C.-Y.; Dong, Y.-P.; Sun, X.; Sui, X.; Zhu, H.; Zhao, Y.-Q.; Zhang, Y.-Y.; Mason, C.; Zhu, Q.; Han, S.-X. High levels of serum glypican-1 indicate poor prognosis in pancreatic ductal adenocarcinoma. Cancer Med. 2018, 7, 5525-5533. [CrossRef] [PubMed]

265. Campbell, D.H.; Lund, M.E.; Nocon, A.L.; Cozzi, P.J.; Frydenberg, M.; de Souza, P.; Schiller, B.; Beebe-Dimmer, J.L.; Ruterbusch, J.J.; Walsh, B.J. Detection of glypican-1 (GPC-1) expression in urine cell sediments in prostate cancer. PLoS ONE 2018, 13, e0196017. [CrossRef] [PubMed]

266. Melo, S.A.; Luecke, L.B.; Kahlert, C.; Fernández, A.F.; Gammon, S.T.; Kaye, J.; LeBleu, V.S.; Mittendorf, E.A.; Weitz, J.; Rahbari, N.N.; et al. Glypican-1 identifies cancer exosomes and detects early pancreatic cancer. Nat. Cell Biol. 2015, 523, 177-182. [CrossRef] [PubMed]

267. Guo, M.; Zhang, H.; Zheng, J.; Liu, Y. Glypican-3: A New Target for Diagnosis and Treatment of Hepatocellular Carcinoma. J. Cancer 2020, 11, 2008-2021. [CrossRef]

268. Li, Y.; Li, M.; Shats, I.; Krahn, J.M.; Flake, G.P.; Umbach, D.M.; Li, X.; Li, L. Glypican 6 is a putative biomarker for metastatic progression of cutaneous melanoma. PLoS ONE 2019, 14, e0218067. [CrossRef]

269. Chandran, V.I.; Welinder, C.; Månsson, A.-S.; Offer, S.; Freyhult, E.; Pernemalm, M.; Lund, S.M.; Pedersen, S.; Lehtiö, J.; MarkoVarga, G.; et al. Ultrasensitive Immunoprofiling of Plasma Extracellular Vesicles Identifies Syndecan-1 as a Potential Tool for Minimally Invasive Diagnosis of Glioma. Clin. Cancer Res. 2019, 25, 3115-3127. [CrossRef]

270. Huang, G.; Lin, G.; Zhu, Y.; Duan, W.; Jin, D. Emerging technologies for profiling extracellular vesicle heterogeneity. Lab. Chip 2020, 20, 2423-2437. [CrossRef]

271. Liu, J.; Moon, A.F.; Sheng, J.-Z.; Pedersen, L.C. Understanding the substrate specificity of the heparan sulfate sulfotransferases by an integrated biosynthetic and crystallographic approach. Curr. Opin. Struct. Biol. 2012, 22, 550-557. [CrossRef] 
272. Clerc, O.; Deniaud, M.; Vallet, S.D.; Naba, A.; Rivet, A.; Perez, S.; Thierry-Mieg, N.; Ricard-Blum, S. MatrixDB: Integration of new data with a focus on glycosaminoglycan interactions. Nucleic Acids Res. 2019, 47, D376-D381. [CrossRef]

273. Vallet, S.D.; Clerc, O.; Ricard-Blum, S. Glycosaminoglycan-Protein Interactions: The First Draft of the Glycosaminoglycan Interactome. J. Histochem. Cytochem. 2020. [CrossRef] 